\title{
Stalked crinoids of the family Bathycrinidae (Echinodermata) from the eastern Pacific
}

\author{
A.N. Mironov \\ P.P. Shirshov Institute of Oceanology, Russian Academy of Sciences, Nakhimovskyi Prospekt 36, \\ Moscow 117997, Russia. \\ e-mail:miron@ocean.ru
}

ABSTRACT: Three crinoid species of the family Bathycrinidae have been found in the Eastern Pacific; depths from 4130 to $6240 \mathrm{~m}$. The species Bathycrinus complanathus was known previously only from northwestern Pacific. A new genus and two new species, Discolocrinus thieli gen. et sp.n. and Bathycrinus mendeleevi sp.n., are described. Six types of pinnule structure are distinguished within the living ten-armed crinoids of the order Bourgueticrinida. One of these types is represented in the Discolocrinus only.

KEY WORDS: Discolocrinus, Bathycrinidae, Bourgueticrinida, Crinoidea, East Pacific, deep-sea fauna, comparative morphological analysis.

\section{Стебельчатые морские лилии семейства Bathycrinidae (Echinodermata) из восточной части Тихого океана}

\begin{abstract}
А.Н. Миронов
Институт океанологии им. П.П. Ширшова РАН, Нахимовский проспект 36, Москва, 117997, Россия.

e-mail:miron@ocean.ru

РЕЗЮМЕ: Три вида морских лилий семейства Bathycrinidae обнаружены в восточной части Тихого океана; глубины от 4130 до 6240 м. Bathycrinus complanathus ранее был известен лишь в северо-западной части Тихого океана. Описаны Discolocrinus thieli gen. et sp.n. и Bathycrinus mendeleevi sp.n. Пиннулы современных десятируких морских лилий отряда Bourgueticrinida по признакам своего строения отнесены к шести типам. Один из этих типов представлен только у Discolocrinus.

КЛЮЧЕВЫЕ СЛОВА: Discolocrinus, Bathycrinidae, Bourgueticrinida, Crinoidea, Bocточная Пацифика, глубоководная морская фауна, сравнительно-морфологический анализ.
\end{abstract}

Printed in 2009 


\section{Introduction}

The stalked crinoids of the deep-sea family Bathycrinidae are found at depths between 520 and $9345 \mathrm{~m}$ in all oceans. Knowledge of eastern Pacific bathycrinid diversity remains very scarce. The taxonomy of these has been dealt with only single paper. A.H. Clark (1908) established Bathycrinus equatorialis on the base of stalk fragments and basal ring taken by Albatross west of the Galapagos Islands (St. $4742,0^{\circ} 3.4^{\prime} \mathrm{N}$, $117^{\circ} 15.8^{\prime} \mathrm{W}, 4220 \mathrm{~m}$ ). In addition Monachocrinus sp. was listed in the catalog of Echinodermata deposited in the Scripps Institution of Oceanography; the specimens were found west of Patton Escarpment, 3600-3676 m (Luke, 1982; Maluf, 1988). The deep-sea photographs of the Peru-Chile Trench floor (6010-6260 m), East Pacific Rise (about $21^{\circ} \mathrm{N}$ and $109^{\circ} \mathrm{W}, 2600$ $2700 \mathrm{~m}$ ) and the abyssal manganese nodule field (between the Clarion and Clipperton fracture zones) show the ten-armed stalked crinoids resembling Bathycrinus (Menzies, 1963; Menzies et al., 1973; Roux, 1980, 1987).

The present study reports on three bathycrinid species found for the first time in the Eastern Pacific. The species Bathycrinus complanathus had been taken previously only by Albatross in the northwestern Pacific (A.H. Clark, 1907a). A new genus and two new species, Discolocrinus thieligen. et sp.n., and Bathycrinus mendeleevi sp.n., are described. Comparative morphological analysis indicates six types of pinnule structure in the extant tenarmed Bourgueticrinida. One of these types is represented in the Discolocrinus thieli only. The subfamily Caledonicrininae Mironov, 2000 is raised to the family level.

\section{Matherial and Terminology}

The material analysed in this study was collected during three expeditions: Cruise 4 of RV Akademic Kurchatov (St. 294), Cruise 20 of RV Dmitry Mendeleyev (St. 1656), and DISCOL 3 Expedition of RV Sonne (St. 77/085). The last sample has been obtained from a manganese nodule area which became a target of the
German DISCOL program (Disturbance and Recolonization Experiment in a Manganese Nodule Area of the Deep South Pacific Ocean) (Borowsky, Thiel, 1998).

Validity of Bathycrinus complanathus is confirmed with a glance to morphological variability of the northern representatives of this species (RV Vityaz, St. 7502) and closely related Arctic species $B$. carpenteri. Together with traditional diagnostic characters some features of the pinnules are used in order to establish new genus and new species. The strucrure of bathycrinid pinnules was not be tested in detail for taxonomic significance. For this reason it was necessary to re-examine the following eleven species of the order Bourgueticrinida.

Bathycrinus australis A.H. Clark - Challenger, St. 146, 46 $36^{\circ} \mathrm{S}, 45^{\circ} 31^{\prime} \mathrm{E}, 2515 \mathrm{~m}$, "type" specimen, Bergen Museum, Cat. No. 722 (labeled as "Bathycrinus aldrichianus") (description of this specimen in Carpenter, 1884 as B. aldrichianus).

B. australocrucis McKnight - Expedition 525 of National Institute of Water \& Atmospheric Research (NIWA), St. D0244, 03.10 $1964,39.5167^{\circ} \mathrm{S}, 171.0000^{\circ} \mathrm{E}, 838 \mathrm{~m}$, paratype (stalk with BB and radix), Cat. No. P-180 (McKnight, 1973).

B. carpenteri Danielssen et Koren - Norwegian North-Atlantic Expedition, St. 53, 10.08 $1876,65^{\circ} 13^{\prime} \mathrm{N}, 00^{\circ} 33^{\prime} \mathrm{E}, 2814 \mathrm{~m}, 4 \mathrm{spms}$, Bergen Museum, Cat. No. 16023 (Danielssen, 1892).

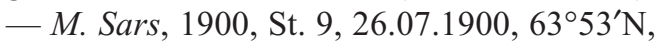
$6^{\circ} 22^{\prime} \mathrm{W}, 1960 \mathrm{~m}$, fragments of $8 \mathrm{spms}$, Bergen Museum, Cat. No. 7701 (Grieg, 1904). - M. Sars, 1902, St. $102,29.08 .1902,63^{\circ} 13^{\prime} \mathrm{N}, 6^{\circ}$ $32^{\prime} \mathrm{W}$, depth $1700 \mathrm{~m}, 3$ spms, Bergen Museum no. 7700 (Grieg, 1904). - Sadko, St. 101, 24.07.1938, $81^{\circ} 50^{\prime} \mathrm{N}, 136^{\circ} 14^{\prime} \mathrm{E}, 3700-3800 \mathrm{~m}$, fragments of stalks, Zoological Institute, SaintPetersburg, Cat. No. 16/11756 (Djakonov, 1946). - Ob, St. 6, 18.08.1956, $78^{\circ} 05^{\prime} 7 \mathrm{~N}, 02^{\circ}$ $25^{\prime} \mathrm{W}, 2870 \mathrm{~m}, 21 \mathrm{spms}$, Zoological Institute, Saint-Petersburg, Cat. No.27/17656 (Koltun, 1964). - Polarstern, Expedition ARK XI/1, St. $60 \mathrm{~b}, 29.08 .1995,80^{\circ} 16^{\prime} 0 \mathrm{~N}, 150^{\circ} 19^{\prime} 5 \mathrm{E}$, $1580 \mathrm{~m}, 11 \mathrm{spms}$, Zoological Institute, SaintPetersburg (Smirnov, Smirnov, 2006). Akademik 
Fedorov, cruise 26, 29.07.2007, submersible “Mir-2", Dive $2 / 413,82^{\circ} 29,70^{\prime} \mathrm{N}, 64^{\circ} 28,05^{\prime} \mathrm{E}$, $1321 \mathrm{~m}, 1 \mathrm{spm}$, Institute of Oceanology, Moscow.

B. gracilis Wyville Thomson - Akademik Mstislav Keldysh, cruise 47, St. 4304, 02.02. $2002,48^{\circ} 11^{\prime} 04 \mathrm{~N}-48^{\circ} 11^{\prime} 77 \mathrm{~N}, 16^{\circ} 05^{\prime} 52 \mathrm{~W}-$ $16^{\circ} 03^{\prime} 64,4120-4553 \mathrm{~m}, 2 \mathrm{spms}$, Institute of Oceanology, Moscow.

B. pacificus A.H. Clark - Albatross, St. $4974,33^{\circ} 18^{\prime} 10^{\prime \prime} \mathrm{N}, 135^{\circ} 40^{\prime} 50^{\prime \prime} \mathrm{E}, 1655 \mathrm{~m}$, holotype, U.S. National Museum, Washington, Cat. No. 22602 (A.H. Clark, 1907b).

Caledonicrinus vaubani Avocat et Roux Alis, Expedition SMIB 4, St. DW 65, 10.03.1989, $22^{\circ} 55,7^{\prime} \mathrm{S}, 167^{\circ} 14,0^{\prime} \mathrm{E}, 400-420 \mathrm{~m}, 1 \mathrm{spm}$., Institute of Oceanology, Moscow (Bourseau et al., 1991).

Cingocrinus radicatus Mironov - Akademik Mstislav Keldysh, Cruise 22, St. 2303, 28-29.07.1990, 545ำ $62 \mathrm{~N}, 165^{\circ} 48^{\prime} 45 \mathrm{E}, 4570$ $\mathrm{m}$, holotype, Institute of Oceanology, Moscow, Cat. No. XV-63-2 (Mironov, 2000).

Monachocrinus aotearoa McKnight - Expedition 1136 of National Institute of Water \& Atmospheric Research (NIWA), St. J0048, 20.04.1970, 36.5000 ${ }^{\circ} \mathrm{S}, 170.4333^{\circ} \mathrm{E}, 2150 \mathrm{~m}$, holotype, Cat. No. H-116 (McKnight, 1973).

M. recuperatus Perrier - Akademik $M$ stislav Keldysh, cruise 47, St. 4304, 02.022002 , $48^{\circ} 11^{\prime} 04 \mathrm{~N}-48^{\circ} 11^{\prime} 77 \mathrm{~N}, 16^{\circ} 05^{\prime} 52 \mathrm{~W}-16^{\circ}$ 03'64 W, 4120-4553 m, 2 spms, Institute of Oceanology, Moscow.

M. sexradiatus A.H. Clark - Ingolf, St 18, $17.061895,61^{\circ} 44^{\prime} \mathrm{N}, 30^{\circ} 29^{\prime} \mathrm{W}, 2075 \mathrm{~m}$, syntype, Zoological Museum, Copenhagen, Cat. No. Cri-65 (A.H. Clark, 1917; A.M. Clark, 1923).

Septocrinus disjunctus Mironov - Dmitry Mendeleyev, cruise 43, St. 4107, 12.04.1989, $41^{\circ} 45,65^{\prime}-41^{\circ} 44,36^{\prime} \mathrm{S}, 41^{\circ} 35,64^{\prime}-41^{\circ} 34,36^{\prime} \mathrm{W}$, 5180-5190 m, holotype, Institute of Oceanology, Moscow, Cat. No. XV-63-4 (Mironov, 2000).

The measurements of calyx, primibrachs and columnals are as in Mironov, 2000, fig. 1. Terminology of morphological characteristics follows that of Breimer (1978) and Roux et al. (2002). The following traditional abbreviations and symbols are used: BB — basals, RR radials, Br - brachial, IBrs1-2 - primibrachs, IIBrs - secundibrachs, Br1, Br2, Br3, .. first, second, third, ... secundibrachs, $\mathrm{P}$ - pinnule, Ps - pinnules, Pn - pinnular, Pns pinnulars. A plus sign $(+)$ indicates a non-muscular (ligamentary) articulation between two brachials. The figures in the brachial formulae show the numbers of consecutive Brs with muscular articulations located between two nonmuscular articulations. For example, a part of the arm with brachial formula $6+5$ consists of 11 Brs, and a non-muscular articulation divides these ossicles into two groups of 6 and $5 \mathrm{Brs}$ with 5 and 4 consecutive muscular articulations. The proximal brachial formulae $1+2,3+4,5,6,7$ or $1+2,3+4,5,6,7,8$ are represented here as $1+2+4$ and $1+2+5$.

\section{Description of species}

\section{Order Bourgueticrinida Sieverts- Doreck \\ Family Bathycrinidae Bather}

Composition of the family: Bathycrinus Thomson, 1872 (type genus), Monachocrinus A. H. Clark, 1917, Cingocrinus Mironov, 2000, Discolocrinus gen.n.

Remarks. The genus Cingocrinus is not firmly established because it was known only from single specimen with regenerated RR-ring and all of arms (Mironov, 2000). Cingocrinus differs from closely related Bathycrinus in having moveable (muscular) joint between Pns beyond the first pair of Pns, more proximal position of $\mathrm{P} 1$ and short columnals in mesistele. A new species of Cingocrinus represented in the collection of the P.P. Shirshov Institute of Oceanology, was taken in the Antarctic. Some tenarmed bourgieticrinids are attributed here to other families: Caledonicrinus Avocat et Roux (in Améziane-Cominardi et al., 1990) - to Caledonicrinidae Mironov, 2000; Septocrinus Mironov, 2000 and Zeuctocrinus A.M. Clark, 1973 - to Septocrinidae Mironov, 2000. Naumachocrinus A.H. Clark, 1912 and the Jurassic Dolichocrinus de Loriol are of doubtful affinity (see discussion below).

Genus Bathycrinus Thomson, 1872

Composition. B. aldrichianus W. Thomson, $B$. australis A.H. Clark, B. australocrucis McKnight, 
Ilycrinus carpenteri Danielssen et Koren, Bathycrinus complanatus A.H. Clark, B. gracilis W. Thomson (type species), B. mendeleevi sp.n., B. pacificus A.H. Clark, B. volubilis Mironov.

Remarks. Roux et al. (2002) refer to the genus Bathycrinus also B. equatorialis A.H. Clark, B. woodmasoni A.H. Clark and B. sibogae A.H. Clark. However these species are too little known to be placed in Bathycrinus. As Gislén (1938) pointed out, $B$. sibogae is a nomen nudum; there are no any records on its morphology. The specimens of $B$. woodmasoni consist of only of stalk fragments. $B$. equatorialis is known from only the stalk fragments and BB. A.H. Clark (1908: 234) noted that the stalk of $B$. equatorialis differs from those of all known species of Bathycrinus, and in general it "bears a striking similarity to the stems of Rhizocrinus". Gislén (1938: 17) wrote about B. equatorialis: "Probably a Bathycrinus, but may perhaps turn out to be a Monachocrinus". The convex sides of the BB-ring, few (9) short columnals in proxistele and not 'dicebox shaped' columnals in mesistele are the features rather of Bourgueticrinidae (Democrinus, Rhizocrinus) than Bathycrinidae.

Bathycrinus complanathus A.H. Clark, 1907 Figs 1, 6A-B.

Bathycrinus complanatus. A.H. Clark, 1907a: 337339, fig. 123 .

Bathycrinus complanatus. A.H. Clark, 1908: 234 236, 237; Gislén, 1938:17.

Ilycrinus complanatus. A.H. Clark, 1915: 62, fig. 3; 1917: 390; Gislén, 1924: 219.

Holotype. RV Albatross, St. 3783, south of Commander Islands, $2840 \mathrm{~m}$, USNM Cat. No. 22662.

Material examined. RV Akademic Kurchatov, Cruise 4, St. $294,01.11 .1968$, Peru Trench, $08^{\circ} 23.1^{\prime} \mathrm{S}, 81^{\circ} 00.8^{\prime} \mathrm{W}$ $6200-6240 \mathrm{~m}$, two RR-rings with bases of arms, RRD 2.00 and $2.37 \mathrm{~mm}$, fragment of arm, and 40 stalk fragments of eight specimens; one of the stalk fragments with BB seems to belong to specimen with RRD $2.37 \mathrm{~mm}$. RV Vityaz, Cruise 59, St. 7502, 22.06.1976, east of Japan Trench, $37^{\circ} 42.0^{\prime} \mathrm{N}, 143^{\circ} 16.2^{\prime} \mathrm{E}, 3620-3640 \mathrm{~m}, 9$ calyces with fragments of arms and stalk, 20 RR-rings with bases of arms, RRD from 1.32 to $5.32 \mathrm{~mm}$, fragments of arms and stalks.

Description. RR-ring low, much broader than high, significantly higher than BB-ring, slightly funnel-shaped or conical. BB-ring low, broader than high, slightly broader above than below. The specimens from Eastern Pacific (St. 294) differ from the specimens taken in Northwestern Pacific (St. 7505) in having more elongate RR and calyx in whole (Fig. 1A-B, Table 1). BB shows no sutures; the larger specimen from St. 294 has indistinct sutures between BB. Tegmen rises up to top of Br4. No visible ossicles on sides of tegmen (in spaces between primibrachs). Anal sac low. Crown laterally slightly compressed. First and second primibrachs broader distally than proximally with smooth surface and marked longitudinal rounded keel; their sides flattened into wide lateral flanges continuing on to secundibrachs. First primibrach usually broader than long (Table 1). Surface of BB, RR, primibrachs and secundibrachs is smooth.

When viewed from interior side one or two large knobby processes visible on the upper part of IBr2, whereas IBr1 without processes. Those on adjacent IBrs 2 impinge upon one another when the arms are closed. Two IBr2 with single knobby process are adjacent; one of them has process on its right part only, and another - on left part. Therefore knobby processes are lacking in one of five interradius. If interradius with anal sac is presumed to be $\mathrm{CD}$, the knobby processes are lacking in the interradius BC. Tegmen in the interradius $\mathrm{BC}$ has deep fissured invagination.

All arms incomplete. The best preserved arm 72 $\mathrm{mm}$ in length (at RRD $4.95 \mathrm{~mm}$ ); it consists of 94 Brs; 21 Ps on side of arm. Profile of arm (viewed from side) smooth. However the fragments of uppermost part of arms with small terminal tooth on each second Brs. Several variants of proximal brachial formula and position of $\mathrm{P} 1$ are found; most frequent of them is $1+3+3+3+2+2$ with $\mathrm{P} 1$ at Br11 (Table 2). Lateral flanges are wide in most proximal Brs and identifiable up to $\mathrm{Br}$ with $\mathrm{P} 1$. Only $\mathrm{P} 1$ and $\mathrm{P} 2$ are complete; they consist of 11 and 13 Pns relatively; the latter $6.45 \mathrm{~mm}$ in length (at RRD $4.95 \mathrm{~mm}$ ). Pns 1-2 shorter than Pns 3-4. In the East Pacific specimens best preserved P consists of 3 Pns; Pn 2 as 1.12 time long as Pn1, and approximately as long as Pn3 (Fig. 1C). Covering plates large, rounded. Side plates absent. Tube feet plates have x-like form.

The longest stalk fragment attached to calyx (RRD $4.95 \mathrm{~mm}$ ) consists of 63 columnals of proxistele and mesistele, $117 \mathrm{~mm}$ in length. Diameter of columnals decreases between $1^{\text {st }}$ and $25^{\text {th }}$ columnals from $1.38 \mathrm{~mm}$ to $1.00 \mathrm{~mm}$, then increases slowly up to $1.52 \mathrm{~mm}$ in $63^{\text {rd }}$ columnal. Lenght of columnals increases between $1^{\text {st }}$ and $63^{\text {rd }}$ from about 0.1 to 3.30 $\mathrm{mm}$. Maximum relation length/diameter of columnal 2.25 in $50-52^{\text {nd }}$ columnals. Among separated fragments the longest and most thick one consists of 49 columnals of mesistele and dististele, $150 \mathrm{~mm}$ in length with maximum diameter $3.87 \mathrm{~mm}$ at dististele. Both Eastern and Northwestern Pacific specimens differ from the type specimens in having more numerous short columnals: 28 in the adult specimen (RRD>2.0 mm) from St. 294 Akademik Kurchatov, 16-25 in the adults from St. 7502 Vityaz (Table 1), and $12-15$ in the type specimens from St. 3783 Albatross. Most elongate columnals always at mesistele. Maximum relation length/diameter of mesistele columnals depends up body size. Maximum relation L/D 3.97 at D $0.56 \mathrm{~mm}$ (of the same colum- 


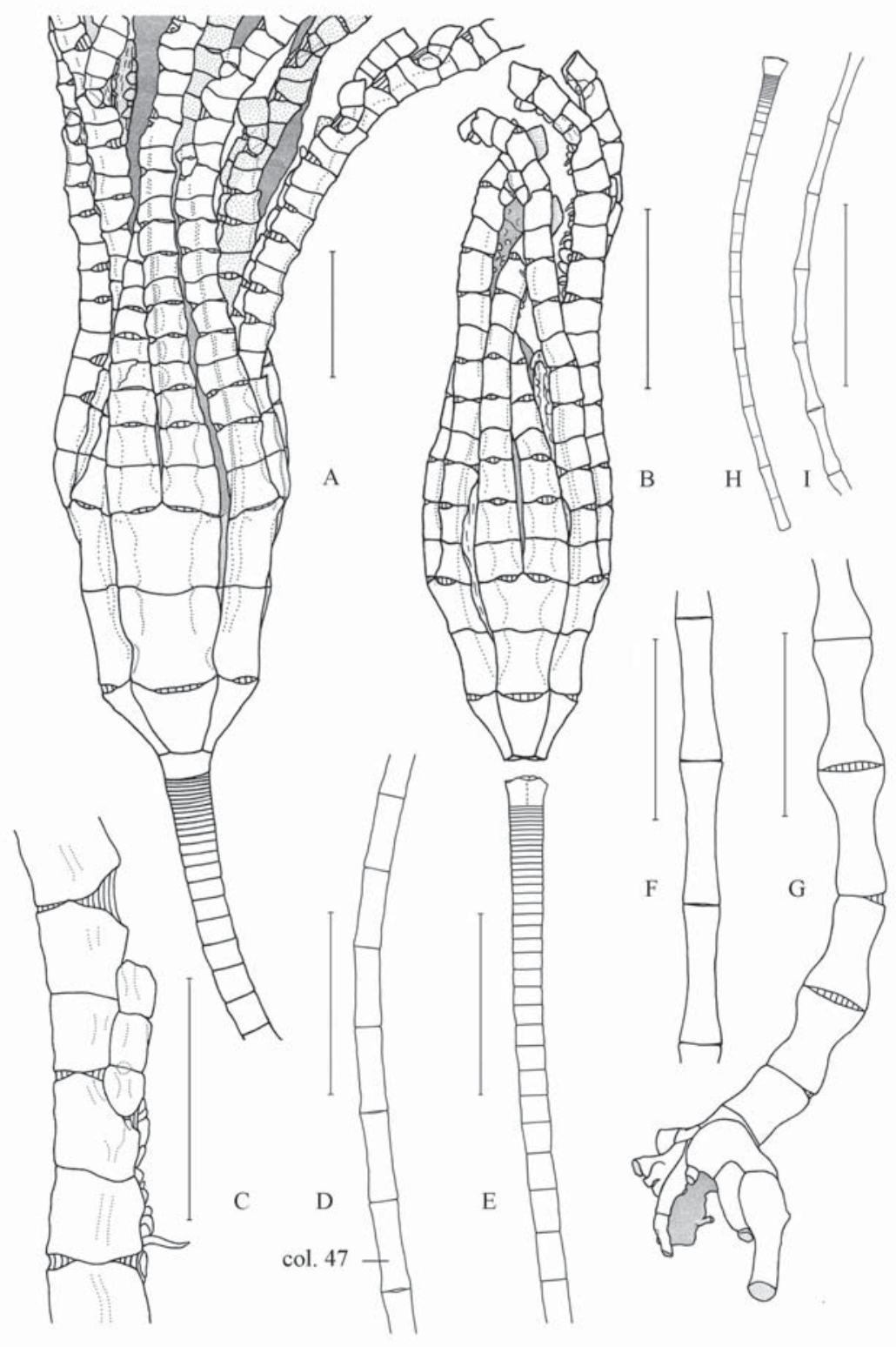

Fig. 1. Bathycrinus complanathus, Vityaz, St. 7502 (A) and Akademik Kurchatov, St. 294 (B-I).

A - calyx with proximal parts of arms and stalk; B - RR-ring with proximal parts of arms; C - fragment of arm, viewed from side; D-E - fragment of proximal part of stalk with BB-ring; F — fragment of mesistele; $\mathrm{G}$ - fragment of dististele with base of radix; $\mathrm{H}$ - fragment of proximal part of stalk with BB-ring, juvenile specimen; I - fragment of stalk, juvenile specimen. Scales: A, B, D-I $-4 \mathrm{~mm}$; C $-2 \mathrm{~mm}$.

Рис. 1. Bathycrinus complanathus, Витязь, ст. 7502 (А) и Академик Курчатов, ст. 294 (В-I). $\mathrm{A}$ - каликс с проксимальными частями рук и стебля; B - RR-кольцо с проксимальными частями рук; C фрагмент руки, вид сбоку; D-E - фрагмент проксимальной части стебля с ВB-кольцом; F — фрагмент мезистеля; $\mathrm{G}$ - фрагмент дистистеля с основанием корневой системы; H - фрагмент проксимальной части стебля с ВВ-кольцом, молодой экземпляр; I - фрагмент стебля, молодого экземпляра. Масштаб: А, В, D-I 4 мм; С-2 мм. 
Table 1. Variability of proportions of RR, BB, Brs and columnals in Bathycrinus complanatus, St. 7502, Vityaz and St. 292, Akademik Kurchatov. Таблица 1. Изменчивость пропорций RR, BB, Brs и члеников стебля у Bathycrinus complanatus, ст. 7502, Витязь и ст. 292, Академик Курчатов.

\begin{tabular}{|l|c|c|c|c|c|c|c|c|c|c|}
\hline \multirow{2}{*}{ Characters } & \multicolumn{9}{|c|}{ St. 7502 } & \multicolumn{3}{c|}{ St. 294 } \\
\cline { 2 - 12 } & 1 & 2 & 3 & 4 & 5 & 6 & 7 & 8 & 1 & 2 \\
\hline Calyx & & & & & & & & & & \\
\hline RRD (mm) & 1.32 & 2.12 & 2.48 & 2.91 & 3.27 & 3.80 & 4.95 & 5.32 & 2.00 & 2.37 \\
\hline CaH/RRD & 0.79 & 0.79 & 0.82 & 0.82 & 0.71 & 0.66 & 0.62 & $?$ & $?$ & 0.84 \\
\hline BBH/RRH & 0.67 & 0.50 & 0.69 & 0.50 & 0.47 & 0.30 & 0.32 & $?$ & $?$ & 0.44 \\
\hline BBd/RRD & 0.33 & 0.31 & 0.30 & 0.31 & 0.31 & 0.31 & 0.28 & $?$ & $?$ & 0.31 \\
\hline RRH/RRD & 0.47 & 0.54 & 0.48 & 0.55 & 0.48 & 0.51 & 0.46 & 0.50 & 0.56 & 0.58 \\
\hline BBH/BBD & 0.69 & 0.67 & 0.75 & 0.68 & 0.59 & 0.44 & 0.44 & $?$ & $?$ & 0.68 \\
\hline Primibrachs & & & & & & & & & & \\
\hline IBr1L/RRH & 1.19 & 1.11 & 1.29 & 1.14 & 1.25 & 1.14 & 1.40 & 1.39 & 1.16 & 0.97 \\
\hline Br1L/Br2L & 1.06 & 1.08 & 1.04 & 1.08 & 1.07 & 1.00 & 1.04 & 1.00 & 1.15 & 1.08 \\
\hline Br1L/Br1W & 1.03 & 0.85 & 0.95 & 0.98 & 0.95 & 0.85 & 0.94 & 1.24 & 0.99 & 0.97 \\
\hline Br2L/Br2W & 1.00 & 0.72 & 0.85 & 0.78 & 0.75 & 0.76 & 0.84 & 0.97 & 0.73 & 0.81 \\
\hline Secundibrachs & & & & & & & & & & \\
\hline Br1L/Br1W & 1.00 & 0.88 & 0.88 & 0.86 & 0.82 & 0.85 & 0.87 & 0.80 & 0.94 & 0.89 \\
\hline Columnals & & & & & & & & & & \\
\hline $\begin{array}{l}\text { Number of short } \\
\text { columnals, L }<\text { D }\end{array}$ & 12 & 24 & 16 & $?$ & 25 & 23 & 22 & $?$ & $?$ & 29 \\
\hline $\begin{array}{l}\text { L/D of 17 } \\
\text { columnal }\end{array}$ & 3.04 & 0.24 & 1.05 & $?$ & 0.29 & 0.24 & 0.42 & $?$ & $?$ & 0.37 \\
\hline $\begin{array}{l}\text { L/D of 34 } \\
\text { columnal }\end{array}$ & $\begin{array}{l}\text { th }(> \\
3.25)\end{array}$ & 2.82 & 3.10 & $?$ & 2.00 & 2.30 & 2.20 & $?$ & $?$ & 2.0 \\
\hline
\end{tabular}

Table 2. Correlation between the proximal brachial formula and position of $\mathrm{P} 1$ in Bathycrinus complanatus, St. 7502, R/V Vityaz.

Таблица 2. Корреляция между проксимальной брахиальной формулой и позицией P1 у Bathycrinus complanatus, ст. 7502, Витязь.

\begin{tabular}{|c|c|c|}
\hline Proximal brachial formula & Position of P1 & Number of arms $(54=100 \%)$ \\
\hline $1+3+3+3+2+2$ & Br 11, outer side of arm & $39(69.6 \%)$ \\
\hline -“- & $\operatorname{Br} 9$, outer side & $2(3.6 \%)$ \\
\hline$-{ }_{-\prime \prime}$ & $\mathrm{Br} 9$, inner side & $2(3.6 \%)$ \\
\hline $1+3+3+2+2+2$ & Br 10 , outer side & $3(5.3 \%)$ \\
\hline -“- & Br 10, inner side & $1(1.8 \%)$ \\
\hline -“- & Br 11, outer side & $1(1.8 \%)$ \\
\hline -“"- & Br 13, outer side & $1(1.8 \%)$ \\
\hline $1+3+3+3+3+2+2$ & Br 12, inner side & $2(3.6 \%)$ \\
\hline $1+3+1+2+2$ & Br 10 , outer side & $1(1.8 \%)$ \\
\hline $1+3+1+3+3+2+3+2$ & Br 12, outer side & $1(1.8 \%)$ \\
\hline $1+3+2+2+2$ & $\mathrm{Br} 9$, outer side & $1(1.8 \%)$ \\
\hline $1+3+3+4+2$ & Br 10 , outer side & $1(1.8 \%)$ \\
\hline $1+2+2+3+3+2$ & Br 12 , outer side & $1(1.8 \%)$ \\
\hline
\end{tabular}

nal), 2.74 at $\mathrm{D} 1.23 \mathrm{~mm}$, and 2.50 at $\mathrm{D} 1.31 \mathrm{~mm}$ in the stalks from St. 7502 ; maximum L/D 5.65 at D 0.56 $\mathrm{mm}, 3.57$ at $\mathrm{D} 0.95 \mathrm{~mm}$, and 3.19 at $\mathrm{D} 0.65 \mathrm{~mm}$ in the stalks from St. 294. Articulation facets circular in proxistele, ovoid in mesistele with transverse position of fulcral ridge, and strongly ovoid in dististele with longitudinal position of fulcral ridge; the latter with regular relief. Root-like radix developed. 


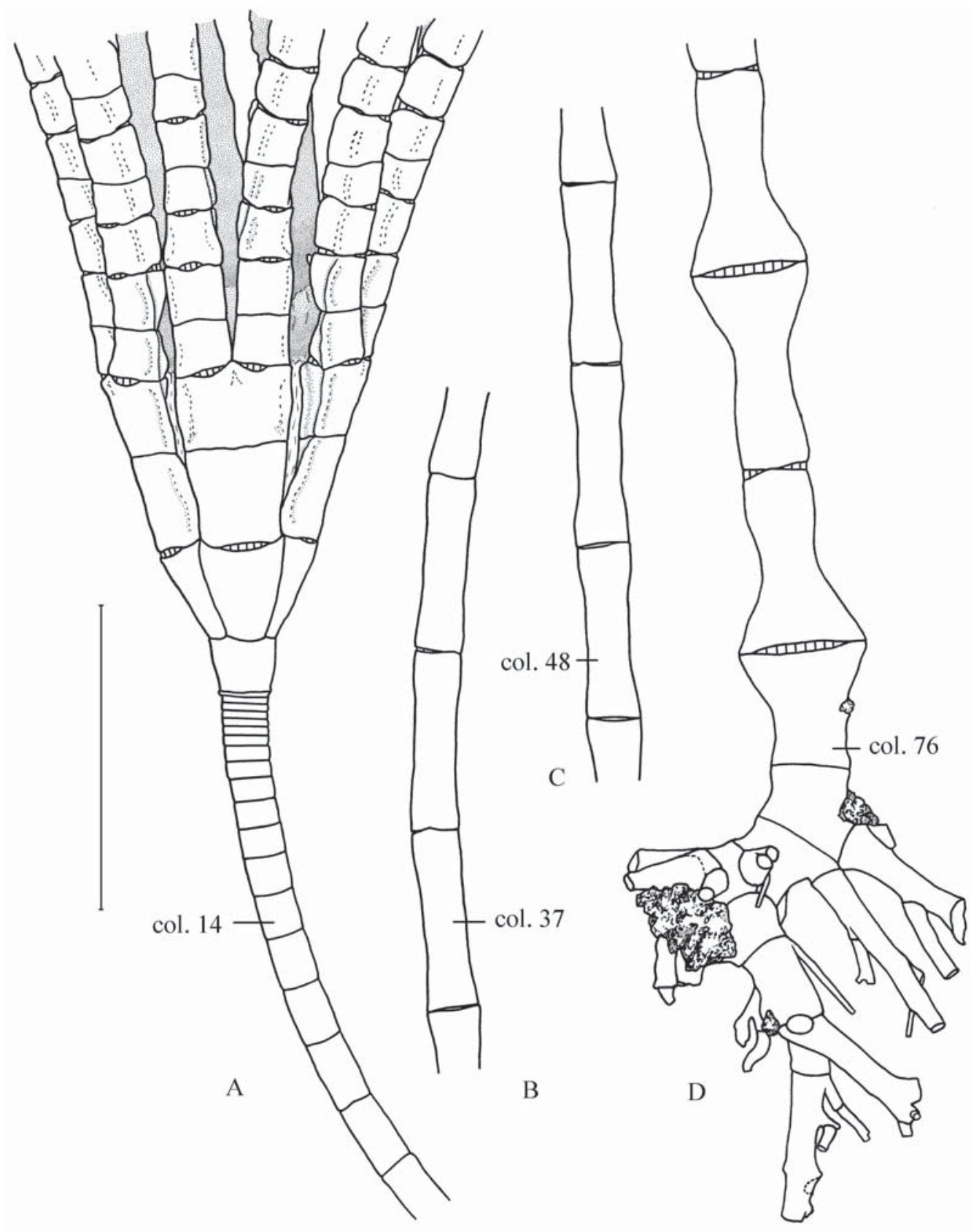

Fig. 2. Bathycrinus mendeleevi sp.n., Dmitry Mendeleyev, St. 1656, holotype.

A - calyx with proximal parts of arms and stalk; B, C - parts of mesistele; D - distal part of stalk with base of radix. Scale: $4 \mathrm{~mm}$.

Рис. 2. Bathycrinus mendeleevi sp.n., Дмитрий Менделеев, ст. 1656, голотип.

А - каликс с проксимальными частями рук и стебля; В, С - части мезистеля; D - дистальная часть стебля с основанием корневой системы. Масштаб: 4 мм. 

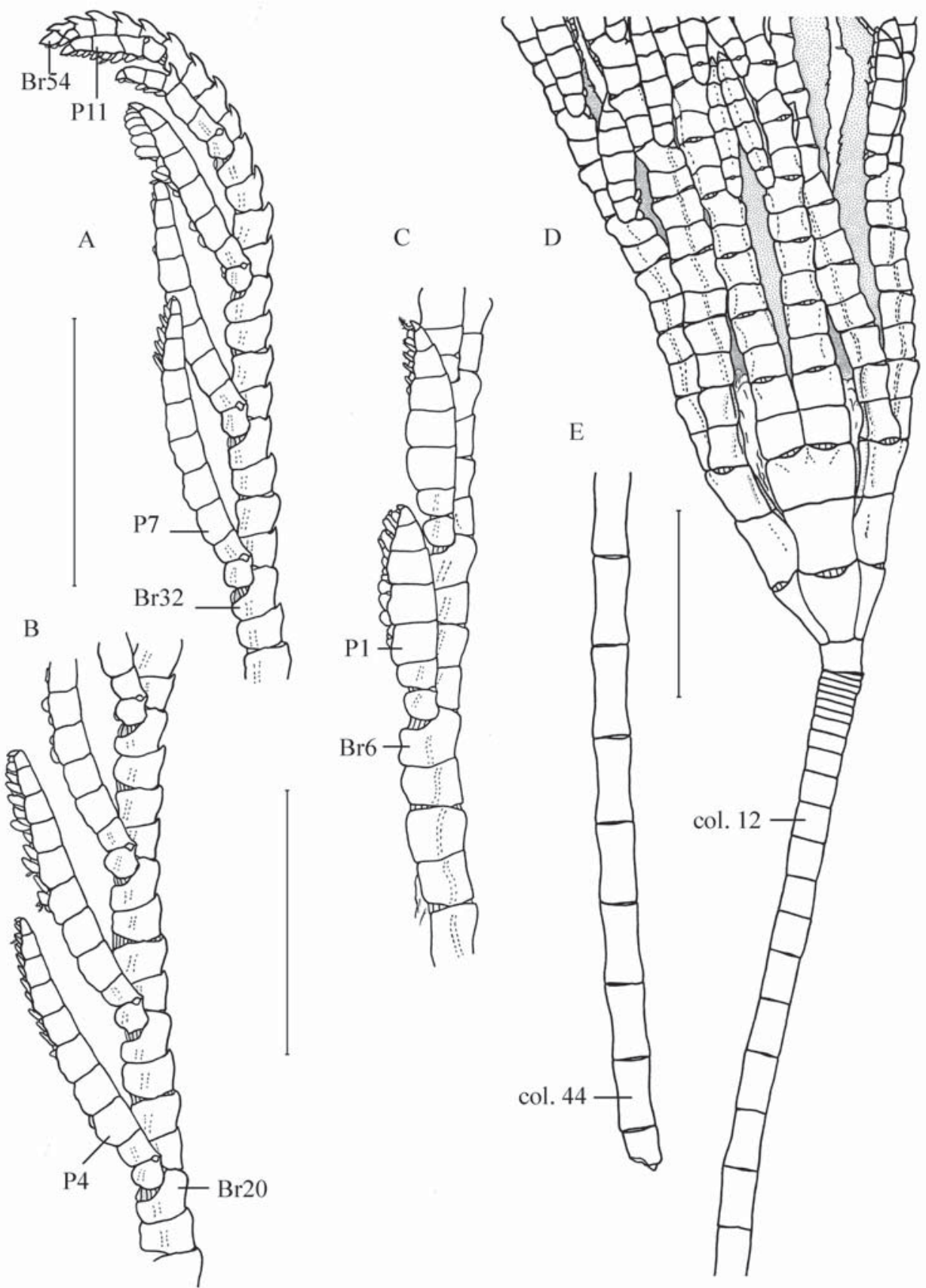

Fig. 3. Bathycrinus mendeleevi sp.n., Dmitry Mendeleyev, St. 1656, paratype with RRD 2.44 mm. A - distal part of arm; B - medial part of arm, C - proximal part of arm with P1, D - calyx with proximal parts of arms and stalk; E - distal part of stalk fragment (mesistele) attached to calyx. Scales: $4 \mathrm{~mm}$.

Рис. 3. Bathycrinus mendeleevi sp.n., Дмитрий Менделеев, ст. 1656, паратип с RRD 2,44 мм. A - дистальная часть руки; В - срединная часть руки, C - проксимальная часть руки с P1, D - каликс с проксимальными частями рук и стебля; Е - дистальная часть фрагмента стебля (мезистель), прикрепленного к каликсу. Масштаб: 4 мм. 
Comparisons. B. complanathus differs from $B$. aldrichianus, B. australis, B. australocrucis, B. gracilis, $B$. mendeleevi and $B$. pacificus in having of smooth profile of arms (for details see a comparison of $B$. mendeleevi sp.n.). The differences from $B$. volubilis are strongly ovoid articulation facets in dististele with regular relief on fulcral ridge, less numerous short columnals in proxistele (up to 69 short columnals in $B$. volubilis) and less prominent median convexity of proximal Brs.

A.H. Clark (1907a: 339) noted that "this species comes nearest to B. carpenteri (Danielssen and Koren) of the northeast Atlantic; but the stem is composed of very much longer and more slender segments, while the lower brachials, which in B. carpenteri are longer than wide, are wider than long, frequently very much so." According to Gislén(1938: 15), B. complanathus can be distinguished from $B$. carpenteri by less numerous short columnals (12-15 in the former and more than 15 in the latter) and low cylindrical BB-ring (BBH/BBD approximately 0.5 in B. complanathus and 1.0 in B. carpenteri). However the study of new material shows a great variability of these morphological features both in $B$. complanathus (Tables 1,2) and B. carpenteri ( Norwegian North-Atlantic Expedition, St. 53; M. Sars, 1900, St. 9; M. Sars, 1902, St. 102; Sadko, St. 101; Ob, St. 6; St. 60b; Akademik Fedorov, Mir-2", Dive 2/413). In particular a number of short columnals varies in adults of $B$. carpenteri from 14 to 31 . Length/width relation in columnals reaches up to 3.77 in B. complanathus and 3.41 in B. carpenteri, but the adult $B$. carpenteri from Sadko St. 101 has extremely elongated columnals with length/width relation up to 6.9. The differences of B. complanathus from $B$. carpenteri are insignificant: higher BB-ring, smooth surface of IIBrs (slightly grooved in $B$. carpenteri), clearly ovate facets of mesistele columnals (round or slightly ovate in B. carpenteri), larger size of body. The relation BBH/BBD is $0.44-0.75$ in $B$. complanathus and $0.63-0.84$ in B. carpenteri. Maximum RRD is $5.32 \mathrm{~mm}$ in $B$. complanathus (Vityaz, St. 7502 ) and $3.63 \mathrm{~mm}$ in B. carpenteri (Akademik Fedorov, St. 2/413).

Distribution. The Peru Trench (or northern part of the Peru-Chile Trench), 6200-6240 m; south of Commander Islands, $2840 \mathrm{~m}$; east of the Japan Trench, 3620-3640 m.

\section{Bathycrinus mendeleevi sp.n.} Figs 2, 3, 4A-H, 5, 6A, 7C.

Holotype. RV Dmitry Mendeleyev, Cruise 20, 21.03 1978 , St. $1656,4800-4950 \mathrm{~m}, 14^{\circ} 52^{\prime} \mathrm{S}, 76^{\circ} 46^{\prime} \mathrm{W}, 4800$ $4950 \mathrm{~m}$, Institute of Oceanology, Moscow; Cat. No. XV63-5.
Material examined. RV Dmitry Mendeleyev, Cruise $20,21.031978$, St. $1656,4800-4950 \mathrm{~m}, 14^{\circ} 52^{\prime} \mathrm{S}, 76^{\circ} 46^{\prime} \mathrm{W}$, 4800-4950 m, 1 specimen with complete arms and stalk (holotype), 8 specimens are represented by calyx, proximal parts of arms and proxistele (paratypes); 17 RR-rings with proximal parts of arms (paratypes), 9 fragments of stalks and some small fragments of arms.

Description. Holotype. $\mathrm{RRD}=2.06 \mathrm{~mm} ; \mathrm{CaH}=$ $2.06 \mathrm{~mm} ; \mathrm{CaH} / \mathrm{RRD}=1.0 ; \mathrm{BBH} / \mathrm{RRH}=0.55 ; \mathrm{BBd} /$ $\mathrm{RRD}=0.31 ; \mathrm{RRH} / \mathrm{RRD}=0.63 ; \mathrm{BBH} / \mathrm{BBD}=0.82$. RR-ring conical, significantly higher than BB-ring, forming with it an angle (Fig. 2A). BB-ring shows no sutures; it broader than high, slightly broader above than below. The surface of RR and BB smooth. Tegmen rises to middle part of IIBr2; rounded plates visible on sides (in spaces between primibrachs). $\mathrm{IBr} 1 \mathrm{~L} / \mathrm{RRH}=1.0 ; \mathrm{IBr} 1 \mathrm{~L} / \mathrm{Br} 2 \mathrm{~L}=1.15 ; \mathrm{IBr} 1 \mathrm{~L} / \mathrm{Br} 1 \mathrm{~W}$ $=1.0 ; \mathrm{IBr} 2 \mathrm{~L} / \mathrm{Br} 2 \mathrm{~W}=0.75$. First and second primibrachs slightly broader distally than proximally, with smooth surface and longitudinal median convexity; their sides flattened into wide lateral flanges continuing on to secundibrachs.

Seven complete arms consist of 41-43 secondary Brs, $23 \mathrm{~mm}$ long (including length of primibrachs). Brachial formula $1+3+3+2+2 \ldots$. etc in eight arms; $1+3+2+2+2$ and $1+3+2+3+2$ in other two arms; $\mathrm{P} 1$ on outer side of $\mathrm{Br} 8$ in nine arms and on outer side of $\mathrm{Br} 9$ in remaining arm. Brs 1-4 with smooth surface and longitudinal median convexity; their sides flattened into lateral flanges. Profile of arms smooth in its proximal part (Brs 1-8) and dentate (not serrate) in median and distal parts. Each second $\mathrm{Br}$ in the median part of arm (Brs 10-22), and each $\mathrm{Br}$ in the distal part of arm has distal tooth.

Number of Ps on side of arm is 8 (9). Length of Ps increases from $2.34 \mathrm{~mm}$ in $\mathrm{P} 1$ to $3.35 \mathrm{~mm}$ in $\mathrm{P} 4$, and decreases more distally. P1 has 7 Pns, Ps 2-6 have 8 Pns each, but distalmost ones reduced. Relative length of Pns variable. However Pn3 always much longer than $\mathrm{Pn} 1$ or Pn2. For example, lengths of Pns 2-8 in relation to the length of Pn1 are as follows in P1 and P5 of the same arm: 1.08/1.69/ $1.69 / 1.37 / 0.95 / 0.31$ (P1) and 1.17/1.45/1.37/1.47/ $1.22 / 1.02 / 0.42$ (P5). Large rounded covering plates developed along the ambulacra; some of them with marked median constriction (Fig. 7C). Genital expansion without additional (genital) plates. Side plates absent. Tube feet plates are $\mathrm{x}$-like.

Stalk complete, $130 \mathrm{~mm}$ long (from calyx to base of radix), consisting of 76 columnals. Columnals of mesistele range from cylindrical to hourglass-shaped. Diameter of columnals decreases between $1^{\text {st }}$ and $16^{\text {th }}$ columnals from $0.60 \mathrm{~mm}$ to $0.52 \mathrm{~mm}$, then increases slowly up to $0.75 \mathrm{~mm}$ in mesistele and up to $1.68 \mathrm{~mm}$ in dististele. Relation length/diameter of columnals increases from 0.14 in proxistele to 3.4 in $35-37^{\text {th }}$, then decreases up to 1.4 in $75^{\text {th }}$ columnal; $14^{\text {th }}$ columnal as long as broad. Root-like radix developed. 


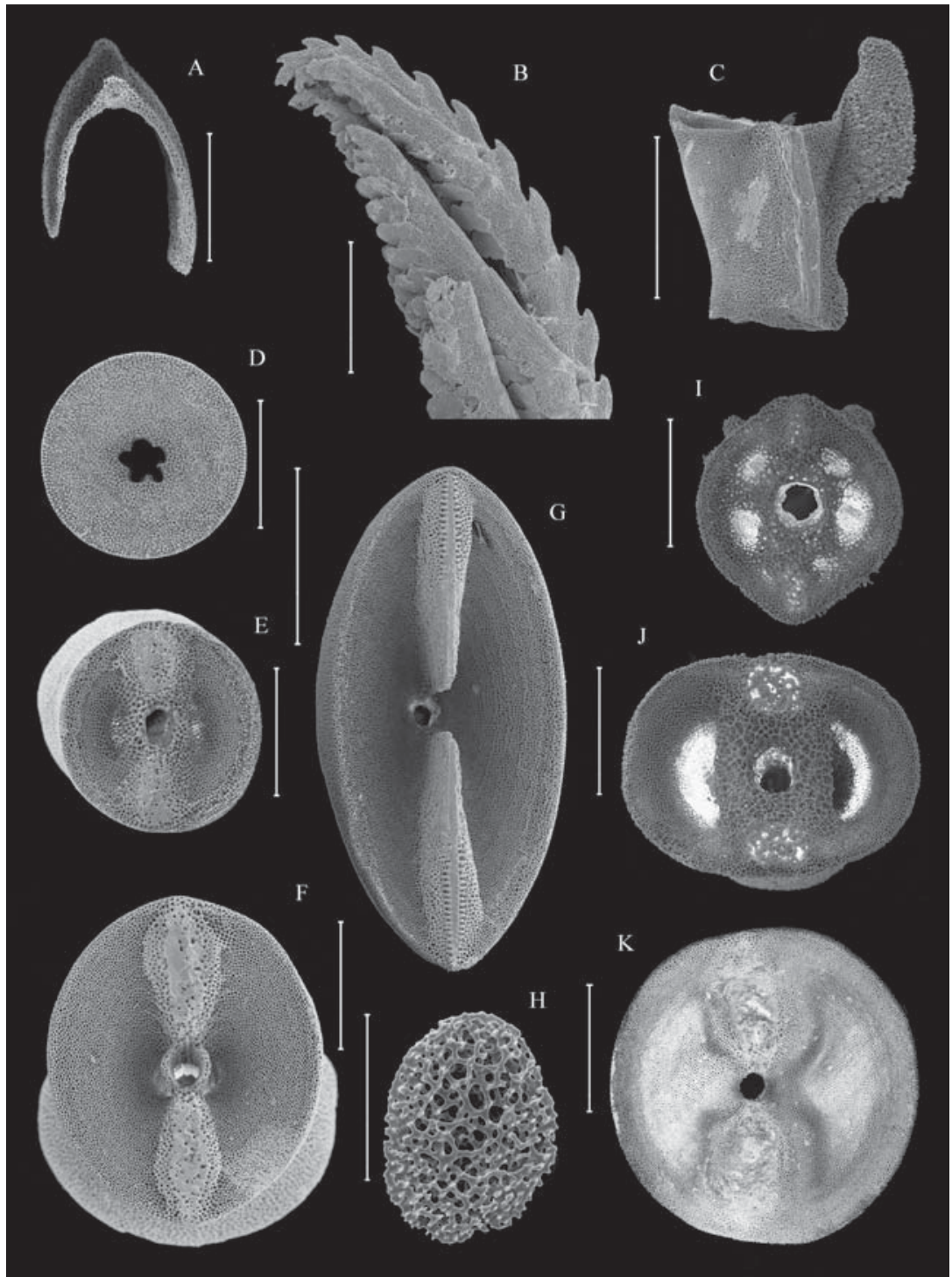

Fig. 4. Bathycrinus mendeleevi sp.n., Dmitry Mendeleyev, St. 1656, paratype 8 with RRD $3.16 \mathrm{~mm}$ (A-E, H) and fragment of stalk (F, G); Discolocrinus thieli, Sonne, DISCOL 3, St. 7, Ship Station 77/085, holotype $(\mathrm{I}-\mathrm{K})$.

A - distal facet of Pn3 in P3; B - distal part of arm with dentate profile; $\mathrm{C}$ - half of IBr2, in oblique view from lateroaboral side, outer surface to left, knobby process to right; D, E - facets of $3^{\text {rd }}(\mathrm{D})$ and $4^{\text {th }}(\mathrm{E})$ columnals counting from calyx; F, G - facets of $17^{\text {th }}(\mathrm{F})$ and $2^{\text {nd }}(\mathrm{G})$ columnals counting from radix; $\mathrm{H}$ - plate from tegmen surface; $\mathrm{I}-\mathrm{K}$ - facets of $17^{\text {th }}, 55^{\text {th }}$ and $84^{\text {th }}$ columnals counting from calyx. Scales: A, D-F $-0.5 \mathrm{~mm} ; \mathrm{B}, \mathrm{C}, \mathrm{G}, \mathrm{I}-\mathrm{K}-1 \mathrm{~mm} ; \mathrm{H}-0.2 \mathrm{~mm}$. Рис. 4. Bathycrinus mendeleevi sp.n., Дмитрий Менделеев, ст. 1656, паратип с RRD 3.16 мм (A-E, H) и фрагмент стебля (F, G); Discolocrinus thieli, Sonne, DISCOL 3, ст. 7, судовой номер станции 77/085, голотип (I-K).

A - дистальная фасетка Pn3 у P3; В - дистальная часть руки с зубчатым профилем; C - половина IBr2, вид с аборально-боковой стороны, наружная поверхность расположена слева, шиповатый вырост - справа; D, E фасетки 3-го (D) и 4-го (E) члеников, считая от каликса; F, G - фасетки 17-го (F) и 2-го (G) члеников, считая от корневой системы; Н - пластинка с поверхности тегмена; I-K - фасетки 17-го, 55-го и 84-го члеников, считая от каликса. Масштаб: A, D-F - 0,5 мм; B, C, G, I-K - 1 мм; H-0,2 мм. 


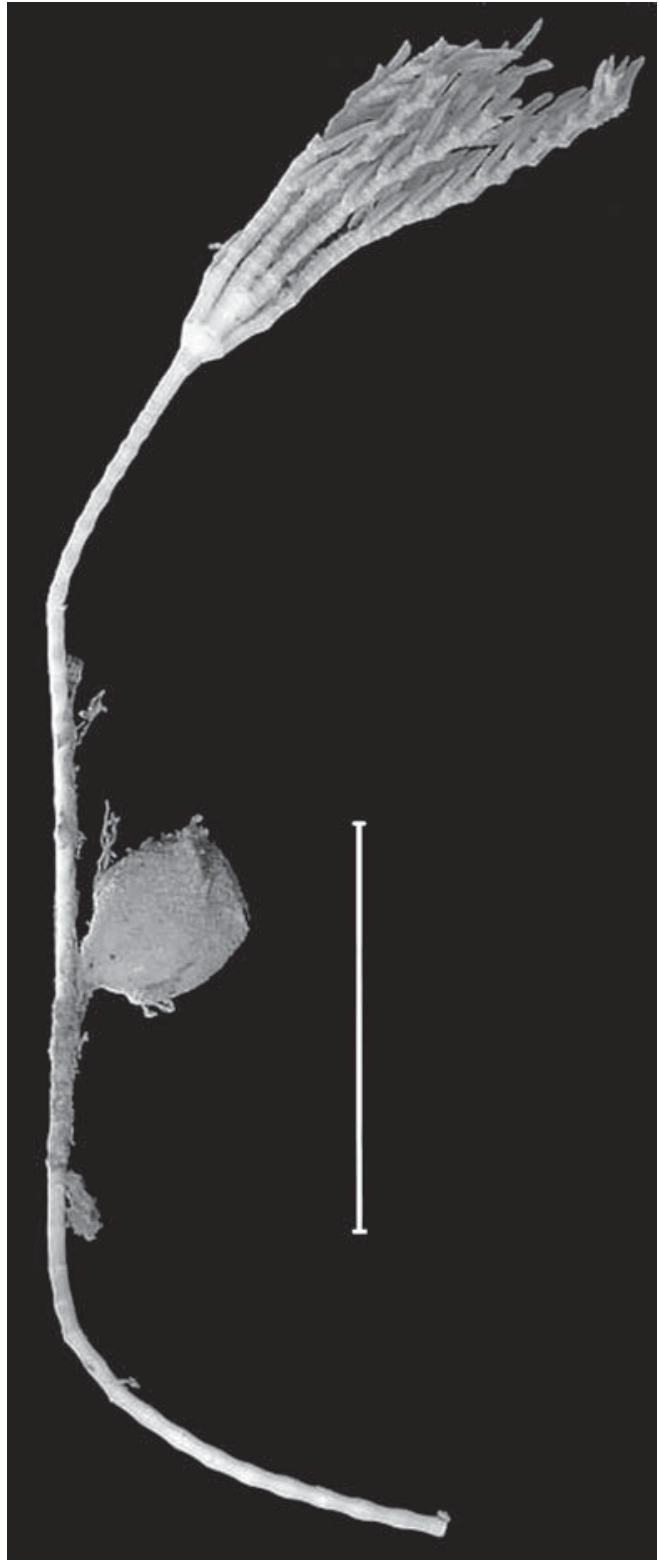

Fig. 5. Bathycrinus mendeleevi sp.n., Dmitry Mendeleyev, St. 1656, paratype with RRD $2.34 \mathrm{~mm}$ An juvenile specimen of stalked ascidian Culeolus anonymus Monniot et Monniot, 1976 attached to mesistele. Scale: $20 \mathrm{~mm}$.

Рис. 5. Bathycrinus mendeleevi sp.n., Дмитрий Менделеев, ст. 1656, паратип с RRD 2,34 мм.

Молодой экземпляр стебельчатой асцидии Culeolus anonymus Monniot et Monniot, 1976 прикреплен к мезистелю. Масштаб: 20 мм.
Paratypes. RRD from 1.53 to $3.16 \mathrm{~mm}$. Relation $\mathrm{BBd} / \mathrm{RRD}$ decreases with size from 0.44 to 0.31 . BB fused or hemi-fused, though sutures may be distinct in the smallest specimens. When viewed from interior two large knobby processes visible on IBr2 (Fig. 4C). Tegmen with rounded plates (Fig. 4H). Number of IIBrs, Ps and Pns increases significantly with body size (Tab. 3). Great variability of the brachial formula and position of P1 (Tab. 4) does not correlated with size. Most frequent brachial formula (55 of 131 arms examined) is $1+3+3+2+2$. Most frequent position of $\mathrm{P} 1(61 \mathrm{arms}$ or $47 \%)$ is on $\mathrm{Br} 8$. Distal part of arm always strongly dentate (Fig. 3A, 4B). Pns V-shaped in cross section, not crescentic (Fig. 4A). Additional (genital) plates of genital expansion are developed at RRD $2.77 \mathrm{~mm}$ (Fig. 6A). Number of short columnals varies from 11 to 15 . Form of upper mesistele columnals from cylindrical to barrel. Articulation facets circular in proxistele and mesistele, and strongly ovoid in dististele; fulcral ridge with regular relief (Fig. 4D-G). The largest specimen (RRD $3.16 \mathrm{~mm}$ ) has anomalies: one of arms has only two Brs between P1 and P2 (usually 3 Brs); Pn6 of P2 with distal tooth. Another specimens with a stalked ascidian attached to mesistele (Fig. 5). This ascidian was identified by Karen Sanamyan as immature Culeolus anonymus Monniot et Monniot.

Comparisons. The main diagnostic character of $B$. mendeleevi sp.n. is strongly dentate profile of arms except for its proximal part. B. volubilis has smooth profile. B. carpenteri and B. complanathus show also smooth profile; the largest specimens have poorly developed dents on few uppermost Brs. $B$. australis and B. pacificus are with slightly dentate profile in median and distal parts of arms; each second $\mathrm{Br}$ in the distal part of arm has distal tooth. $B$. australocrucis is with dentate profile from base to tip of arm. B. aldrichianus and B. gracilis have strongly serrate profile with each $\mathrm{Br}$ flared distally. $B$. mendeleevi sp.n. differs also from $B$. australis, $B$. aldrichianus, B. carpenteri, B. complanathus, B. gracilis and $B$. volubilis in proximal position of $\mathrm{P} 1$ and less numerous short columnals in proxistele, whereas $B$. australocrucis and $B$. pacificus agree with the new species in position of P1. B. mendeleevi sp.n. can be distinguished from $B$. pacificus by smooth surface of Brs, relatively lower BB and less numerous short columnals; the holotype of $B$. pacificus has slightly grooved $\mathrm{Brs}$ (with longitudinal ribs on the surface), 25 short columnals, $\mathrm{BBH} / \mathrm{BBD}=1.01$ and $\mathrm{BBH} /$ $\mathrm{RRH}=0.73$. Additional differences from $B$. australocrucis are smooth profile of proximal part of arm, lower calyx and RR-ring. The calyx of the holotype of B. australocrucis has following proportion (McKnight, 1973, Fig. 1): CaH/RRD 1.19, BBd/RRD 0.45 and RRH/RRD 0.81. I examined the stalk with BB of the paratype of B. australocrucis, NIWA St. D0244. 
Table 3. Age variability of arms in Bathycrinus mendeleevi sp.n., St. 1656, R/V Dmitryi Mendeleyev. Таблица 3. Возрастная изменчивость рук у Bathycrinus mendeleevi sp.n., ст. 1656, Дмитрий

\begin{tabular}{|c|c|c|c|c|c|c|c|c|c|}
\hline Characters & 1 & 2 & 3 & 4 & 5 & 6 & 7 & 8 & 9 \\
\hline RRD (mm) & 1.82 & 2.06 & 2.14 & 2.37 & 2.42 & 2.57 & 2.61 & 2.77 & 3.16 \\
\hline $\mathrm{BBd}(\mathrm{mm})$ & $?$ & 0.60 & 0.69 & $?$ & 0.90 & $?$ & 0.89 & $?$ & 1.00 \\
\hline $\begin{array}{l}\text { *Length of arms } \\
(\mathrm{mm})\end{array}$ & $?$ & 23.0 & 22.5 & 24.5 & 32.0 & 38.0 & 30.1 & $?$ & $?$ \\
\hline Number of IIBrs & $?$ & 43 & 43 & 47 & 53 & $59-60$ & 56 & $?$ & $?$ \\
\hline $\begin{array}{l}\text { Number of Ps on } \\
\text { side }\end{array}$ & $?$ & $8(9)$ & $9(10)$ & 10 & $11-12$ & $13-14$ & $12-13$ & $?$ & $?$ \\
\hline $\begin{array}{l}\text { Length of P1 } \\
\text { (minimum, mm) }\end{array}$ & $\begin{array}{c}2.23 \\
\text { (on } \\
\text { Br8) }\end{array}$ & $\begin{array}{c}2.34 \\
\text { (on } \\
\text { Br8) } \\
\end{array}$ & $\begin{array}{c}2.25 \\
\text { (on } \\
\text { Br5) } \\
\end{array}$ & $\begin{array}{c}2.57 \\
\text { (on } \\
\text { Br7) } \\
\end{array}$ & $\begin{array}{c}3.2 \\
\text { (on } \\
\text { Br7) } \\
\end{array}$ & $\begin{array}{c}3.04 \\
\text { (on } \\
\text { Br7) } \\
\end{array}$ & $\begin{array}{c}3.62 \\
\text { (on } \\
\text { Br5) } \\
\end{array}$ & $\begin{array}{c}3.23 \\
\text { (on } \\
\text { Br8) } \\
\end{array}$ & $\begin{array}{c}3.66 \\
\text { (on } \\
\mathrm{Br} 7 \text { ) }\end{array}$ \\
\hline $\begin{array}{l}\text { Number of Pns } \\
\text { in P1 }\end{array}$ & 7 & 7 & 6 & 7 & 7 & 7 & 8 & $7-8$ & $7-8$ \\
\hline The largest $\mathrm{P}$ & $?$ & 4 th & 5 th & 5 th & 5 th & $5-6$ th & $6-7$ th & $7-8$ th & $?$ \\
\hline $\begin{array}{l}\text { Their maximum } \\
\text { length }\end{array}$ & $?$ & 3.35 & 3.66 & 3.95 & 4.70 & 5.33 & 5.58 & 6.23 & $?$ \\
\hline Number of Pns & $?$ & 8 & 9 & 10 & 11 & 12 & 13 & 13 & $?$ \\
\hline
\end{tabular}

*Length of the largest arm among 5 arms of each specimen including the length of IBrs 1-2.

*Длина самой крупной руки среди 5 рук каждого экземпляра, включая длину IBrs 1-2.

Table 4. Variability of the proximal brachial formula and position P1 in Bathycrinus mendeleevi, St. 1656, R/V Dmitryi Mendeleyev.

Таблица 4. Изменчивость проксимальной брахиальной формулы и позиции Р1 у Bathycrinus mendeleevi, ст. 1656, Дмитрий Менделеев.

\begin{tabular}{|c|c|c|}
\hline $\begin{array}{l}\text { Proximal brachial } \\
\text { formula }\end{array}$ & Position of P1 (number of arm) & $\begin{array}{c}\text { Number of arms } \\
(\%)\end{array}$ \\
\hline $1+3+3+2+2$ & $\mathrm{Br} 8(36), \mathrm{Br} 6(15)$ and $\mathrm{Br} 9(4)$ & $55(42 \%)$ \\
\hline $1+3+2+2+2$ & $\operatorname{Br} 5$ (7), Br7 (5), Br9 (4) and Br6 (2) & $18(14 \%)$ \\
\hline $1+3+3+3+2$ & $\operatorname{Br} 9(11)$ and $\operatorname{Br} 8(1)$ & $12(9 \%)$ \\
\hline $1+3+2+3+2$ & $\mathrm{Br} 8(9)$ and $\mathrm{Br} 7(1)$ & $10(8 \%)$ \\
\hline $1+3+4+2+2$ & $\mathrm{Br} 7(8)$ and $\mathrm{Br} 8(1)$ & $9(7 \%)$ \\
\hline $1+2+2+2+2$ & $\operatorname{Br} 8(8)$ & $8(6 \%)$ \\
\hline $1+5+2+2+2$ & Br5 (2) and Br7 (1) & $3(2 \%)$ \\
\hline $1+3+3+1+2$ & $\operatorname{Br} 9(2)$ & $2(1.5 \%)$ \\
\hline $1+3+1+2+2$ & Br6 (1) and Br8 (1) & $2(1.5 \%)$ \\
\hline $1+3+5+2+2$ & $\operatorname{Br} 8(2)$ & $2(1.5 \%)$ \\
\hline $1+2+3+2+2$ & Br7 (2) & $2(1.5 \%)$ \\
\hline $1+1+2+1+3+2$ & Br9 (1) & $1(<1 \%)$ \\
\hline $1+2+1+3+2$ & $\operatorname{Br8}(1)$ & $1(<1 \%)$ \\
\hline $1+2+2+3+2$ & Br8 (1) & $1(<1 \%)$ \\
\hline $1+2+3+4+2$ & Br9 (1) & $1(<1 \%)$ \\
\hline $1+3+1+1+2$ & Br7 (1) & $1(<1 \%)$ \\
\hline $1+3+1+1+2+3+2$ & Br9 (1) & $1(<1 \%)$ \\
\hline $1+3+3+2+3+2+1+1+2$ & Br8 (1) & $1(<1 \%)$ \\
\hline $1+4+2+2+2$ & Br6 (1) & $1(<1 \%)$ \\
\hline Total & $\mathrm{Br} 8$ (61), Br9 (24), Br6 (19), Br7 (18) and Br5 (9) & $131(100 \%)$ \\
\hline
\end{tabular}



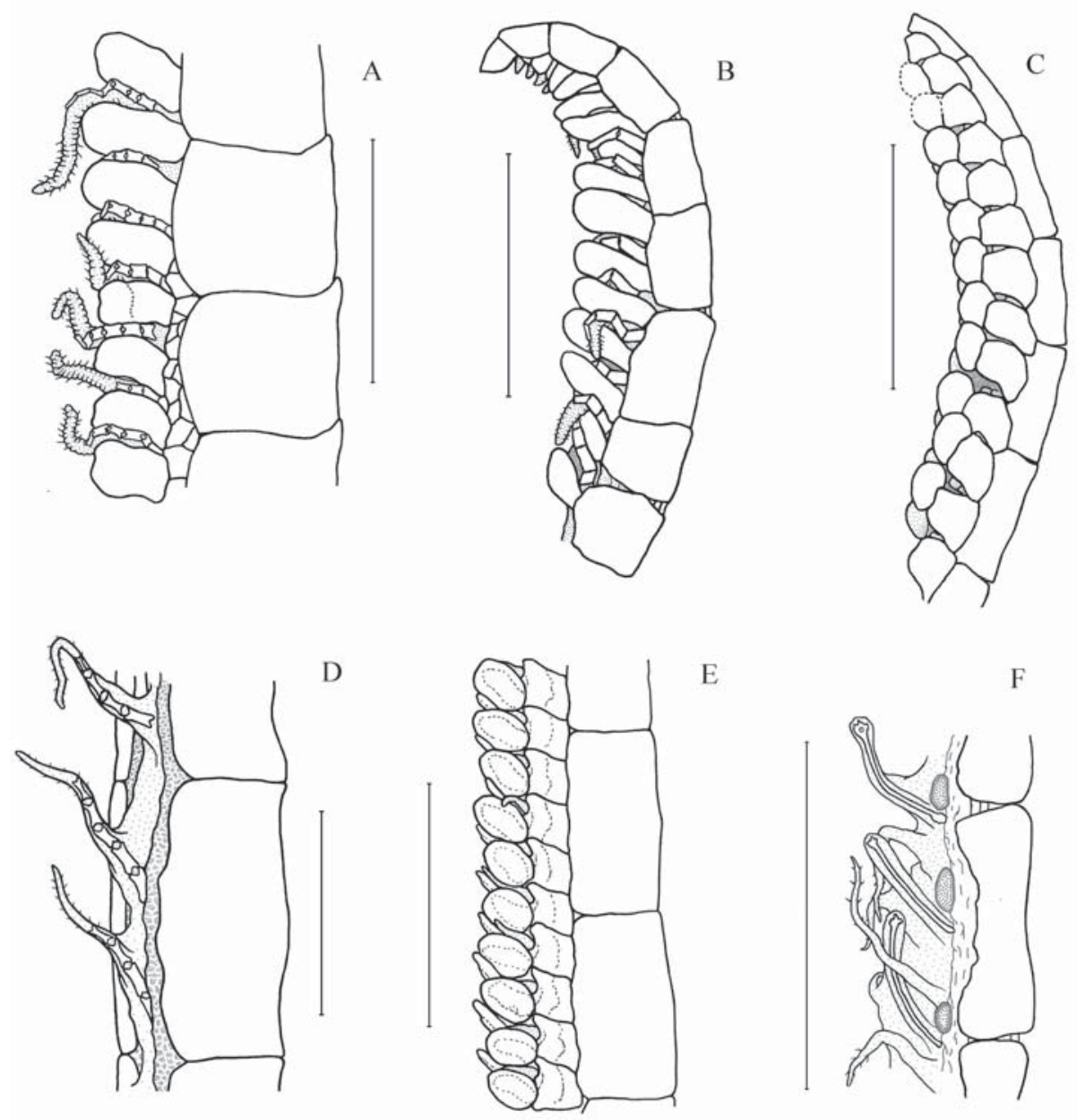

E

$\mathrm{F}$

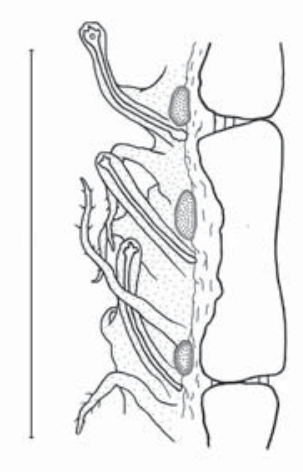

Fig. 6. Six types of pinnule structure in the stalked crinoids of the families Bathycrinidae (A-D), Caledonicrinidae (E) and Septocrinidae (F); viewed from side (A-C, E, F) and in oblique view from laterooral side (D).

A - Bathycrinus mendeleevi sp.n., Dmitry Mendeleyev, Cruise 20, St. 1656; B - Cingocrinus radicatus, Akademik Mstislav Keldysh, Cruise 22, St. 2303; C - Monachocrinus sexradiatus, Ingolf, INGOLF Expedition, St 18; Discolocrinus thieli gen. and sp.n., Sonne, DISCOL 3, St. 7 (schematic reconstruction); E - Caledonicrinus vaubani, Alis, Expedition SMIB 4, St. DW 65; F - Septocrinus disjunctus, Dmitry Mendeleyev, cruise 43, St. 4107 (schematic reconstruction). Scales: $1 \mathrm{~mm}$.

Рис. 6. Шесть типов структуры пиннулы у стебельчатых морских лилий семейств Bathycrinidae (AD), Caledonicrinidae (E) и Septocrinidae (F); вид сбоку (A-C, E, F) и орально-боковой стороны (D). A - Bathycrinus mendeleevi sp.n., Дмитрий Менделеев, рейс 20, ст. 1656; В - Cingocrinus radicatus, Академик Мстислав Келдыш, рейс 22, ст. 2303; С - Monachocrinus sexradiatus, Ingolf, экспедиция INGOLF, ст. 18; Discolocrinus thieli gen. and sp.n., Sonne, экспедиция DISCOL 3, ст. 7 (схематическая реконструкция); E Caledonicrinus vaubani, Alis, экспедиция SMIB 4, ст. DW 65; F — Septocrinus disjunctus, Дмитрий Менделеев, рейс 43, ст. 4107 (схематическая реконструкция). Масштаб: 1 мм.

It consists of 47 columnals, $41.6 \mathrm{~mm}$ in length, $\mathrm{BBd}$ $0.61 \mathrm{~mm}, \mathrm{BBH} / \mathrm{BBD} 0.78,12$ short columnals, the most elongated columnal 3.3 time as long as wide.
The stalk of $B$. australocrucis differs from that of $B$. mendeleevi sp.n. in having slightly ovoid (not round) articulation facets of mesistele columnals with trans- 
verse position of fulcral ridge, and less ovoid articulation facets in dististele.

Distribution. Between Peru and Chile parts of the Peru-Chile Trench, 4800-4950 m.

\section{Discolocrinus gen.n.}

Type species. Discolocrinus thieli sp.n.

Diagnosis. Calyx composed of both basals and radials, slightly funnel-shaped, much broader than high. BB fused. RR-ring without upper interradial projections. Both $\mathrm{IBr} 1$ and $\mathrm{IBr} 2$ extremely elongated, much longer than calyx. Expanded proximal ends of IBrs1 contiguous, whereas other parts of division series widely separated from each other. $\mathrm{IBr} 2$ with inner knobby process. Tegmen high, covered by very thin reticulate plates. Brachial formula $1+2+2+2+2 \ldots ;$ P1 on Brs 11-14. Sutures between secundibrachs not oblique (dorsal view). Ps strongly compressed laterally, with pinnulars that are Vshaped in cross-section. Covering (ambulacral), side (adambulacral) plates and rod-like spicules absent in ambulacral grooves. Bases of ambulacral tube feet are covered by $x$-like plates. Numerous low cylindric columnals of proxistele with median thorns. Columnals of mesistele elongated, hourglass-shaped. Columnal articulation both in proxistele and dististele circular; those in mesistele elliptical with transverse position of fulclar ridge. Fulcral ridge in all columnals, including lowermost, with irregular relief. Stalk cements to hard substrate via an expanded terminal columnal with few extremely short radicles.

Composition. Only type species.

Etymology. The genus name Discolocrinus comes from the type locality (German DISCOL experimental area of the Deep East Pacific).

Comparisons. Discolocrinus gen.n. differs from other bathycrinid genera in having several unique features. It can be easily distinguished from Bathy- crinus, Cingocrinus and Monachocrinus by its laterally compressed pinnules without covering plates (Figs 6, 7), more elongated primibrachs, presence of thorns on proximal columnals, circular articulations in dististele, few very short rootlets. Only two species of the Bathycrinidae, Discolocrinus thieli sp.n. and $B$. volubilis, have an irregular relief on fulcral ridge of the distal columnals. The new genus is similar in brachial formula $(1+2+2+2+2)$ to Monachocrinus.

\section{Discolocrinus thieli sp.n.} Figs 4I-K, 6D, 8.

Holotype. RV Sonne, DISCOL 3, St. 7, Ship Station 77/085, 13.02.1992, Kastengreifer 1363, Peru Basin, $07^{\circ}$ $04.00^{\prime} \mathrm{S}, 88^{\circ} 29.08^{\prime} \mathrm{W}, 4131 \mathrm{~m}$, manganese nodule field; calyx with proximal parts of arms and stalk; small fragments of arms and stalk; the specimen dried and in a bad condition, with numerous breaks of very fragile Brs and Ps; deposited in Forschungsinstitut und Naturmuseum Senckenberg, Frankfurt am Main, Germany.

Material examined. Holotype only.

Etymology. This species is named in honour of Hjalmar Thiel for his contributions to our knowledge of deep-sea fauna, including benthic fauna of the abyssal manganese nodule fields.

Description. $\mathrm{RRD}=5.23 \mathrm{~mm} ; \mathrm{CaH}=3.23 \mathrm{~mm}$; $\mathrm{BBd}=2.01 \mathrm{~mm} ; \mathrm{CaH} / \mathrm{RRD}=0.62 ; \mathrm{BBH} / \mathrm{RRH}=$ $0.61 ; \mathrm{BBd} / \mathrm{RRD}=0.38 ; \mathrm{RRH} / \mathrm{RRD}=0.38 ; \mathrm{BBH} /$ $\mathrm{BBD}=0.47$. Calyx low, slightly funnel-shaped (Fig. 8A, I). RR-ring conical, higher than BB-ring, forming with the latter an evenly sloping line. BB-ring shows no sutures; it broader than high, slightly broader above than below. Tegmen is well visible owing to wide space between the primary Brs. It is covered by very thin plates with composite reticulate relief. These plates have rounded irregular form, slightly overlapping. Tegmen high, rising laterally to

Fig. 7. Plates and spicules on the pinnules; the families Bathycrinidae (A-G), Caledonicrinidae (F-K) and Septocrinidae (L).

A-B - Bathycrinus complanathus, Vityaz, Cruise 59, St. 7205, covering (A) and tube feet (B) plates; C - Bathycrinus mendeleevi sp.n., Dmitry Mendeleyev, Cruise 20, St. 1656, covering plates; D-E - Cingocrinus radicatus, Akademik Mstislav Keldysh, Cruise 22, St. 2303, covering (D) and tube feet (E) plates; F-G - Monachocrinus sexradiatus, Ingolf, INGOLF Expedition, St 18, covering (F) and side (G) plates; H-K - Caledonicrinus vaubani, Alis, Expedition SMIB 4, St. DW 65, covering plates vieved from outer (H) and inner (I) sides, and side plates from outer (J) and upper sides (K); L - Septocrinus disjunctus, Dmitry Mendeleyev, cruise 43, St. 4107, large rode-like spicules. Scales: $0.1 \mathrm{~mm}$. Рис. 7. Пластинки и спикулы, располагающиеся на пиннулах; семейства Bathycrinidae (A-G), Caledonicrinidae $(\mathrm{F}-\mathrm{K})$ и Septocrinidae $(\mathrm{L})$.

A-B - Bathycrinus complanathus, Buтязь, рейс 59, ст. 7205, пластинки покровные (А) и амбулакральных ножек (B); C - Bathycrinus mendeleevi sp.n., Дмитрий Менделеев, рейс 20, ст. 1656; покровные пластинки; D-E Cingocrinus radicatus, Академик Мстислав Келдыш, рейс 22, ст. 2303, пластинки покровные (D) и амбулакральных ножек; F-G - Monachocrinus sexradiatus, Ingolf, экспедиция INGOLF, ст 18, покровные (F) и боковые (G) пластинки; H-K - Caledonicrinus vaubani, Alis, экспедиция SMIB 4, ст. DW 65, покровные пластинки при виде с внешней $(\mathrm{H})$ и внутренней (I) сторон, и боковые прластинки при виде с внешней (J) и верхней $(\mathrm{K})$ сторон; $\mathrm{L}-$ Septocrinus disjunctus, Дмитрий Менделеев, рейс 43, ст. 4107, крупные стержневидные спикулы. Масштаб: 0,1 мм. 


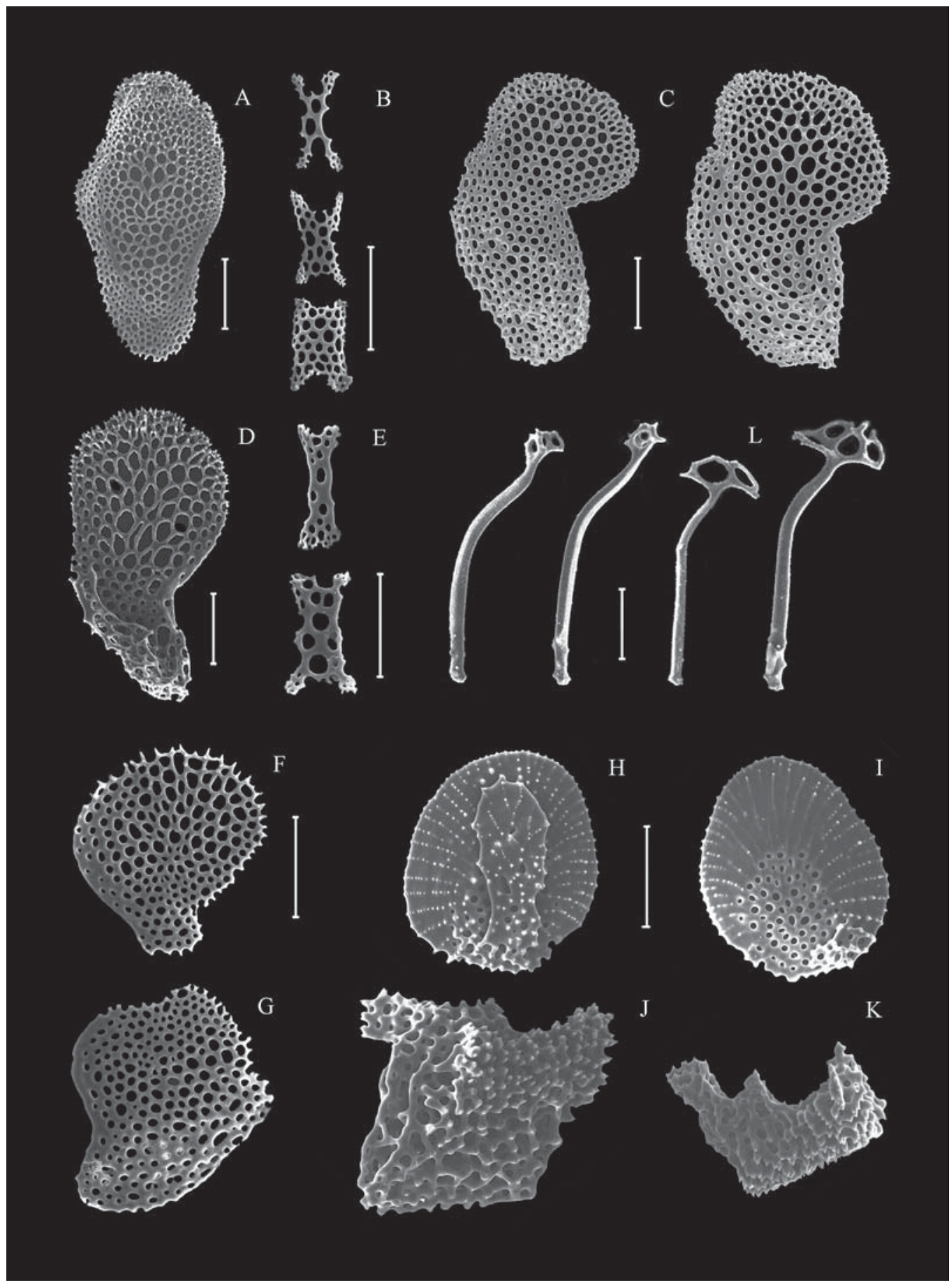


top of IIBr1; its upper central part at the level of Br3 top. Both IBr1 and IBr2 extremely elongated, much longer than calyx, with smooth surface and longitudinal median convexity; their sides flattened into wide lateral flanges continuing on to secundibrachs. $\mathrm{IBr} 1 \mathrm{~L} / \mathrm{RRH}=3.10, \mathrm{Br} 1 \mathrm{~L} / \mathrm{Br} 2 \mathrm{~L}=1.16, \mathrm{Br} 1 \mathrm{~L} / \mathrm{Br} 1 \mathrm{~W}$ $=1.87, \mathrm{IBr} 2 \mathrm{~L} / \mathrm{Br} 2 \mathrm{~W}=1.52$. Expanded proximal ends of IBrs 1 contiguous laterally whereas remaining division series are widely separated from each other. $\mathrm{IBr} 2$ with inner knobby process. One of the division series anomalous with three primary Brs (Fig. 8I); the third primibrach divided by indistinct longitudinal suture into two unequal left and right parts.

All arms incomplete; best preserved arm consists of $16 \mathrm{Brs}, 46 \mathrm{~mm}$ in length (including the length of IBrs1-2). Brachial formulae $1+2+2+2$ with one exception: $2+2+2$ in an arm with anomalous short IIBr1 (Fig. 8I). P1 on Brs 11-14. IIBrs elongated, longer than wide, with smooth surface and longitudinal median convexity; IIBr $1 \mathrm{~L} / \mathrm{IIBr} 1 \mathrm{~W}=0.47$. The sides of Brs 1-5 flattened into lateral flanges (Fig. $8 \mathrm{~A}, \mathrm{I}, \mathrm{K})$. The sides of $\mathrm{Br} 5$ and more distal Brs consist of stereom with large cells, which sharply transforms into very thin margins with numerous small perforations. Profile of arms smooth.

All Ps are incomplete; the most preserved P consist of $11 \mathrm{Pns}, 11 \mathrm{~mm}$ in length; a complete $\mathrm{P}$ had likely about 16 Pns. Ps V-shaped in cross section, strongly compressed laterally (Figs 6D, 8J). Pns 36 are much higher than more distal Pns. There is fragment of most distal part of $\mathrm{P}$ with 5 low tiny Pns. Articulation between all Pns beyond the first pair is rigid. The most surface of Pns with composite reticulate relief; very thin margins of Pns usually broken, with smooth surface. Narrow space between opposite margins of Pn (ambulacral groove) is covered by thin skinny membrane which has calcite ramifications and carries vertical membrane. The latter unites a row of long ambulacral tube feet (Fig. 6D). Each ambulacral tube foot has small $\mathrm{x}$-like plates arranged in longitudinal row (Fig. 8M), up to 12 plates on a tube foot. Side and covering plates absent.
There are 15 fragments, representing the most of the stalk and consisting of 87 columnals; total length of the fragments $404 \mathrm{~mm}$. Fragment attached to cup $9.7 \mathrm{~mm}$ long; consisting of 16 columnals (the $16^{\text {th }}$ one incomplete) (Fig. 8A). Diameter of columnals decreases between $1^{\text {st }}$ and $24^{\text {th }}$ columnals from 2.0 $\mathrm{mm}$ to $1.7 \mathrm{~mm}$, then increases slowly up to $2.6 \mathrm{~mm}$ in $86^{\text {th }}$ columnal (numeration is conventional because small part of mesistele was lost). Length of columnals increases between $1^{\text {st }}$ and $61^{\text {st }}$ columnals from $0.2 \mathrm{~mm}$ to $8.8 \mathrm{~mm}$; then decreases up to $3.3 \mathrm{~mm}$ in $86^{\text {th }}$ columnal. Relation length/height of columnals increases from 0.1 in proxistele to 3.8 in $62^{\text {nd }}$ columnal, then decreases up to 1.3 in $86^{\text {th }}$ columnal.; number of short proximal columnals (length < diameter) 16 .

Columnals 7-38 with 5 thorns (or less) on medial part of each columnal (Fig. 8A-D). On every suture between proximal columnals (no. 8-25) two opposite tubercles, which located along fulcral axis. Columnals of mesistele hourglass-shaped. Articulate facets pentagonal in columnals $1-7$, round in columnals $8-25$, ovate with transverse fulcral ridge from $26^{\text {th }}$ to about $65^{\text {th }}$ columnal (Fig. $4 \mathrm{~J}$ ); round or slightly ovate with longitudinal fulcral ridge in columnals 66-86. Fulcral ridge in distal columnals with irregular relief (Fig. 4K). Stalk attached to small rounded ferromanganese nodule by expanded terminal columnal; two very short flattened rootlets reinforce its attachment (Fig. 8G, H).

\section{Discussion}

Six types of pinnule structure can be distinguished within the order Bourgueticrinida (Tab. 5 ; Figs 6,7). Bathycrinus-type is best characterized by rows of large covering plates bordering ambulacral grooves on both sides. Some covering plates have well-marked constriction in the middle part (Fig. 6C). It is likely that this constriction is a trace indicating coalescence of two

Fig. 8. Discolocrinus thieli, Sonne, DISCOL 3, St. 7, Ship Station 77/085, holotype.

A - calyx with proximal parts of arms and stalk; B-E - fragments of mesistele; F - fragment of dististele; G-H fragment of dististele with expanded terminal columnal and few very short unbranched radicles, viewed from two sides; $\mathrm{I}$ - proximal parts of two anomalous arms; J - fragment of arm, viewed from dorsal side; $\mathrm{K}$ - three first secundibrachs; $\mathrm{L}-$ fragment of arm, viewed from side; $\mathrm{M}-\mathrm{x}$-like plates of ambulacral tube foot. Scales: A-I $-10 \mathrm{~mm}$; J-L -5 $\mathrm{mm} ; \mathrm{M}-0.5 \mathrm{~mm}$.

Рис. 8. Discolocrinus thieli, Sonne, экспедиция DISCOL 3, ст. 7, судовой номер станции 77/085, голотип.

А - каликс с проксимальными частями рук и стебля; В-E - фрагменты мезистеля; F — фрагменты дистистеля; $\mathrm{G}-\mathrm{H}$ - фрагмент дистистеля с расширенным терминальным члеником и немногочисленными очень короткими неразветвленными корешками, вид с двух сторон; I — проксимальная часть двух аномальных рук; J — фрагмент руки, вид с оральной стороны; $\mathrm{K}$ - три первые вторичные брахиали; $\mathrm{L}$ - фрагмент руки при виде сбоку; $\mathrm{M}$ X-образные пластинки амбулакральной ножки. Масштаб: A-I - 10 мм; J-L -5 мм; M - 0,5 мм. 
Stalked crinoids from eastern Pacific

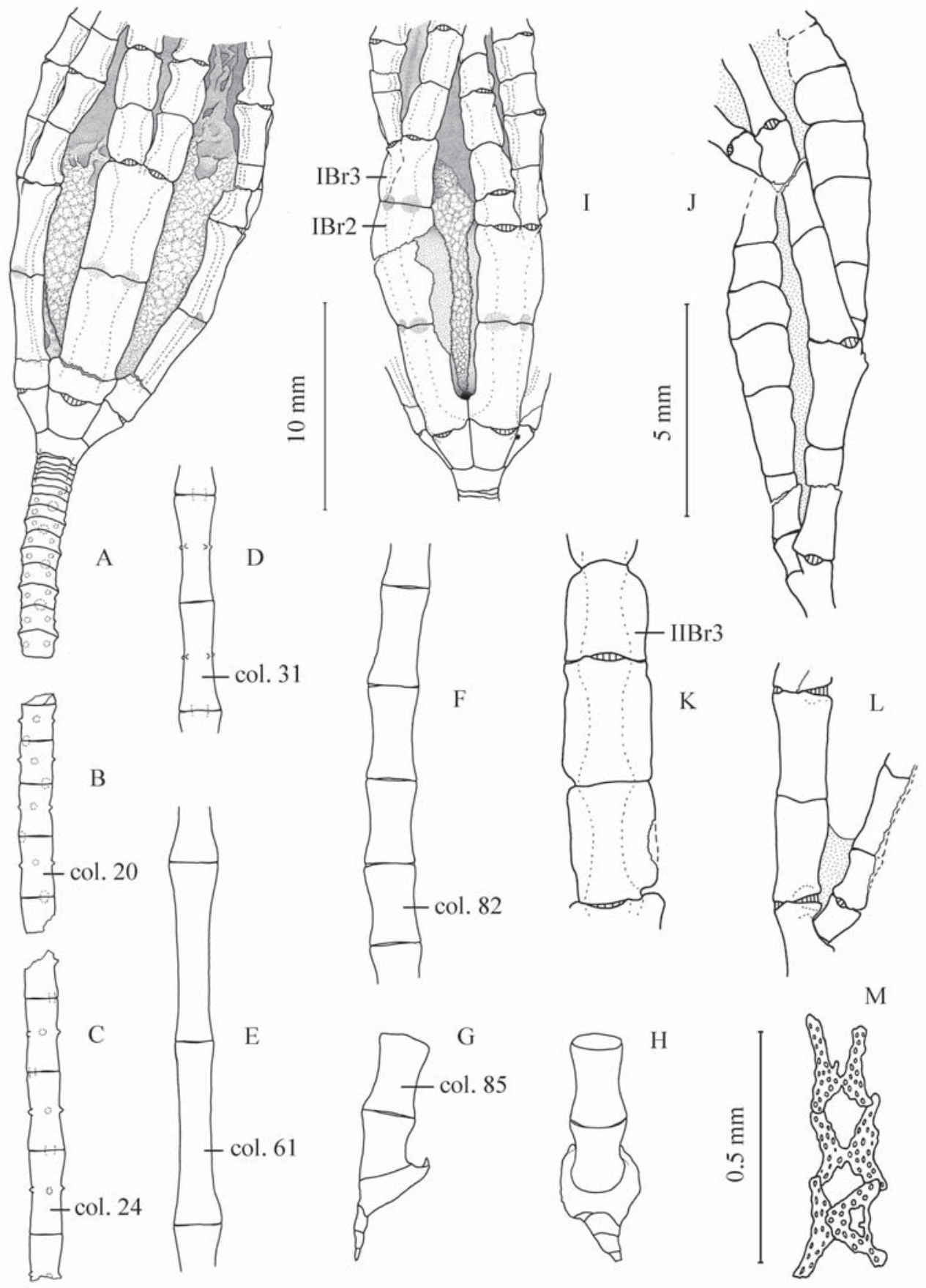


plates: the covering and the side ones. The articulation between all Pns beyond the first pair is rigid; articulation facets without distinct transverse ridge. Each tube foot with a row of x-like plates. This type of Ps was known for $B$. aldrichianus (Carpenter, 1884, Pl. VIII, Fig. 5), $B$. australis (Carpenter, 1884, Pl. VII, Fig. 7), B. carpenteri (Danielssen, 1892, Pl. I, Fig. 12) and B. volubilis (Mironov, 2000, Fig. 2. 6, 7). It is found now in B. complanatus (Fig. 7A, B), B. gracilis (Akademik Mstislav Keldysh, St. 4304), B. mendeleevi sp.n. (Figs 6A, 7C) and B. pacificus (Albatross, St. 4974, holotype). In the monotypic genus Cingocrinus Ps have also large covering plates. But Ps of Cingocrinus differ from those in other genera in having alternate rigid and moveable (muscular) joints between Pns. The moveable (muscular) articulation in Cingocrinus are with transverse ridge separating two bevelled sides of the articular surface. Tube feet with $\mathrm{x}$-like plates (Figs 6B, 7D, E). Covering and side plates are lacking in Discolocrinus; Ps are strongly compressed laterally; narrow space between opposite margins of Pn (ambulacral groove) is covered by thin skinny membrane which has calcite ramifications and carries vertical membrane. The membrane unites a row of long ambulacral tube feet with x-like plates (Figs. 6D, 8J, L, M, holotype). In Monacocrinus each ambulacral groove bordered by covering and side plates; both are rounded. There are 1-3 small rod-like or branched spicules (reduced x-like plates?) at the base of tube foot. This type is found in M. sexradiatus (Figs 6C, 7F, G, syntype), M. recuperatus (Akademik Mstislav Keldysh, St. 4304) and M. aotearoa McKnight, 1973 (NIWA, St. J0048, holotype).

Caledonicrinus of the family Caledonicrinidae Mironov, 2000 has also both covering and side plates. As contrasted with Monachocrinus the side and covering plates are quite different: the former are quadrilateral with inner and lateral processes, whereas the latter are ovoid with numerous radial tuberculate ridges (Figs 6E, $7 \mathrm{H}-\mathrm{K})$. Each covering plate is attached to a special articulate facet on the upper surface of adjacent side plate (Fig. 7J, K). Ps are always Vshaped in cross-section in all above mentioned genera. Septocrinidae Mironov, 2000 (Septocrinus and Zeuctocrinus) differ from other bourgueticrinid genera in having crescentic (in crosssection) Pns and large rod-like spicules and in lacking the covering, side and tube feet plates (Figs 6F, 7L). Septocrinus-type of pinnules is characterized also by presence of well deweloped sacculae lying at the bases of tube feet. Structure of Ps is not known with certainty for the genera Bourgueticrinus d'Orbigny, Dunnicrinus Moore, Conocrinus d'Orbigny, Naumachocrinus A.H. Clark, Phrynocrinus A.H. Clark and Porphyrocrinus Gislen.

The genera Caledonicrinus and Naumachocrinus were attributed to Bathycrinidae by Bourseau et al. (1991), Roux et al. (2002), and to the subfamily Caledonicrininae of the family Bathycrinidae by Mironov (2000). Oji \& Kitazawa (2008) who have examined new material on Naumachocrinus assigned this genus also to the Bathycrinidae. However Caledonicrinus and Naumachocrinus differ significantly from all other bathycrinids in having cryptic BB-ring, convex sides of the RR-ring, more proximal position of P1 (on Brs 4-5), cylindrical or barrel-shaped (not dice-box or hourglassshaped) columnals of mesistele, expanded terminal columnal (not root-like radix).

The subfamily Caledonicrininae Mironov, 2000 is considered here as a separate family Caledonicrinidae, since some additional morphological and molecular evidences support strongly a separation of Caledonicrinus from Bathycrinidae at a high taxonomic level. Given its neuroanatomical features, Caledonicrinus may form a group of its own (Heinzeller et al., 1995). Molecular analysis of high-level interrelationships among extant crinoids (Cohen at al., 2004) has identified a clade where Caledonicrinus is united with members of the order Cyrtocrinida (Gymnocrinus and Holopus). In addition to features above mentioned, Caledonicrinus has other significant differences from the bathycrinids: numerous muscular articulations in arms, presence of $\mathrm{P}$ on every second Brs (on a side of arm), lacking (as well as in Septocrinidae) of knobby processes on primibrachs and $\mathrm{x}$-like plates in the tube feet. The form of 
Table 5. Types of pinnule strucrure among 10-armed crinoids of the order Bourgueticrinida. Таблица 5. Типы структуры пиннул у десятируких морских лилий отряда Bourgueticrinida.

\begin{tabular}{|l|c|c|c|c|c|c|}
\hline \multicolumn{1}{|c|}{ Characters } & \multicolumn{5}{c|}{ Types of pinnule strucrure } \\
\cline { 2 - 7 } & Ba & Mo & Ci & Di & Ca & Se \\
\hline Pinnulars in cross-section V-shaped (+) or crescentic (-) & + & + & + & + & + & - \\
\hline $\begin{array}{l}\text { Articulation between all Pns beyond the first pair is rigid } \\
(+), \text { moveable (-) or they alternate (+/-) }\end{array}$ & + & + & $+/-$ & + & + & - \\
\hline Covering plates present (+) or absent (-) & + & + & + & - & + & - \\
\hline Side plates present (+) or absent (-) & - & + & - & - & + & - \\
\hline Covering and side plates are similar (+) or quite different (-) & & + & & & - & \\
\hline Large rod-like spicules (in Ps) present (+) or absent (-) & - & - & - & - & - & + \\
\hline $\begin{array}{l}\text { Tube-feet plates present (+), absent (-), or there are 1 -3 } \\
\text { small rod-like or branched spicules (reducing plates?) in a } \\
\text { base of foot (+/-). }\end{array}$ & + & $+/-$ & + & + & - & - \\
\hline
\end{tabular}

Abbreviations: Ba - Bathycrinus, Mo - Monachocrinus, Ci - Cingocrinus, Di - Discolocrinus (Bathycrinidae), $\mathrm{Ca}$ - Caledonicrinus (Caledonicrinidae), $\mathrm{Se}$ - Septocrinus (Septocrinidae).

Сокращения: $\mathrm{Ba}$ - Bathycrinus, $\mathrm{Mo}$ - Monachocrinus, $\mathrm{Ci}$ - Cingocrinus, Di - Discolocrinus (Bathycrinidae), $\mathrm{Ca}-$ Caledonicrinus (Caledonicrinidae), $\mathrm{Se}-$ Septocrinus (Septocrinidae).

covering and side plates in Caledonicrinus is also quite distinct.

A mode of reinforcement of the arm bases is quite different in Bathycrinidae, Caledonicrinidae and Septocrinidae. The inner knobby processes on adjacent primibrachs come into contact with each other in Bathycrinidae. Oblique ridges on the sides of IIBrs 1-2 interlock with corresponding grooves on the sides of adjacent IIBrs 1-2 in Caledonicrinus. Primibrachs are placed between high interradial partition-walls (septa) on the calyx in Septocrinus.

A position of Naumachocrinus in Caledonicrinidae is questionable. A cryptobasal ring in Naumachocrinus might be only a convergence with Caledonicrinus. The calyx of Naumachocrinus is slightly if at all wider than stalk and RR extremely tall and narrow, whereas the calyx of Caledonicrinus is much wider than stalk and RR are rather low. I expect that Naumachocrinus differs from Caledonicrinus in having another structure of Ps.

Bourseau et al. (1991) and Améziane \& Roux (1997) suggested that the Jurassic genus Dolichocrinus de Loriol might be the oldest representative of the family Bathycrinidae. This genus is known only from RR-circlets which are extremely high and similar to that of Naumachocrinus (Rasmussen \& Sieverts-Doreck, 1978). According to Rasmussen \& Sieverts-
Doreck (1978), Dolichocrinus is a genus of uncertain taxonomical affinity (Order and Family uncertain). Pisera \& Dzik (1979) and Salamon \& Gorzelak (2007) attributed it to Cyrtocrinida.

\section{Acknowledgements}

I would like to thank the following people who have generously loaned to me specimens used in this study: Cynthia Ahearn, David Pawson (Smithsonian Institution, National Museum of Natural History, Washington), Nadia Améziane (Muséum National d'Histoire Naturelle, Paris), Dieter Fiege, Michael Türkay (Forschungsinstitut und Naturmuseum Senckenberg, Frankfurt am Main), Jon Anders Kongsrud (Museum of Zoology, University of Bergen), Claus Nielsen (Zoological Museum, University of Copenhagen), Kareen Schnabel (National Institute of Water \& Atmospheric Research, Wellington), Alexei Smirnov (Zoological Institute, St. Petersburg).

\section{References}

Améziane-Cominardi N., Bourseau J.P., Avocat R., Roux M. 1990. Les Crinoïdes pédonculés de NouvelleCalédonie: inventaire et réflexions sur les taxons archaïques // De Ridder C., Dubous P., Lahaye M.C., Jangoux M. (eds.). Echinoderms trough time. Proceedings Second European Colloquium on Echino- 
derms. Brussel, 18-21 Sept. 1989. Rotterdam: Balkema. P.117-124.

Améziane N., Roux M. 1997. Biodiversity and historical biogeography of stalked crinoids (Echinodermata) in the deep sea // Biodiversity and Conservation. Vol.6. P.15557-1570.

Borowsky C., Thiel H. 1998. Deep-sea macrofaunal impacts of a large-scale physical disturbance experiment in the Southeast Pacific // Deep-Sea Research II. Vol.45. P. 55-81.

Bourseau J.-P., Améziane-Cominardi N., Avocat R., Roux M. 1991. Echinodermata: Les Crïnoides pédonculés de Nouvelle-Calédonie (Résultats des Campagnes Musorstom. Vol.8) // Mémoires du Muséum National d'Histoire Naturelle. Vol.A151. P.229-333.

Breimer A. 1978. General morphology. Recent crinoids. // R.C. Moore, C. Teichert (eds.). Treatise on Invertebrate Paleontology, Part T, Echinodermata 2. Vol.1. Lawrence: Geological Society of America and University of Kansas Press. P.9-58.

Carpenter P.H. 1884. Report on the Crinoidea collected during the Voyage of H.M.S. «Challenger» during the years 1874-1876. The stalked crinoids // Report on the Scientific Results of the Voyage of H.M.S. Challenger (Zoology). Vol.11. P.1-442.

Clark A.H. 1907a. Five new recent crinoid from the North Pacific Ocean // Smithsonian Miscellaneous Collections. Vol. 4. No.3. P.337-342.

Clark A.H. 1907b. Two new crinoids from the North Pacific Ocean // Proceedings of the United States National Museum. Vol.32. No.1543. P.507-512.

Clark A.H. 1908. Notice of some Crinoidea in the collection of the Museum of comparative zoology // Bulletin of the Museum of Comparative Zoology at Harvard College. Vol.51. No.8. P.233-248.

Clark A.H. 1912. Naumachocrinus, a new genus belonging to the crinoid family Phrynocrinidae // Proceedings of the United States National Museum. Vol.42. No.1895. P.195-197.

Clark A.H. 1915. A monograph of the existing crinoids. 1. The comatulids, Part $1 / /$ Bulletin of the United States National Museum. Vol.82. No.1. P.1-406.

Clark A.H. 1917. A revision of the recent genera of the crinoid family Bourgueticrinidae with the description of a new genus // Journal of the Washington Academy of Sciences, U.S.A. Vol.7. No 5. P.388-392.

Clark A.H. 1923. Crinoidea // The Danish Ingolf Expedition. Vol.4. Part 5. P.1-58.

Clark A.M. 1973. Some new taxa of recent stalked Crinoidea // Bulletin of the British Museum (Natural History), Zoology. Vol.25. No.7. P.267-288.

Cohen B. L., Améziane N., Eleaume M., Richer de Forges B. 2004. Crinoid phylogeny: a preliminary analysis (Echinodermata: Crinoidea) // Marine Biology. Vol.144. No.3. P.605-617.

Danielssen D.C. 1892. Crinoida // The Norwegian NorthAtlantic Expedition 1876-1878. Zoology. Vol.21. P.1-28.

Djakonov A.M. 1946. [New and interesting species of
Echinodermata from the northern Arctic Ocean] // Trudy dreifuyushchei ekspeditsii Glavsevmorputy na ledokol'nom parokhode «G. Sedov», 1937-1940 gg. Vol.3. P.324-332 [in Russian, with English summary].

Gislén T. 1924. Echinoderm studies // Zoologiska Bidrag fram Uppsala. Vol.9. P.1-316.

Gislén T. 1938. A revision of the recent Bathycrinidae // Lunds Universitets Arsskrift, N.F. Vol.34. No.10. P.1-30.

Grieg J.A. 1904. Echinodermen von dem norwegischen Fischereidampfer «Michael Sars» in den Jahren 19001903 gesammelt // Bergens Museum Aarborg. No.5. S.1-39.

Heinzeller T., Améziane-Cominardi N., Fricke H., Welsch U. 1995. Isocrinida (Crinoidea) compared with nonisocrinid forms: Nervous supply of stalk and stem // Verhandlung der Deutschen Zoologischen Gesellschaft. Vol.88. P.34.

Koltun V.M. 1964. [To knowledge of benthic fauna of the Greenland Sea and central part of the Arctic Basin] // V.M. Koltun, L.L. Balakshin (eds.). [Scientific results of the high-Arctic expeditions in the north part of the Greenland Sea and adjacent regions of the Arctic Basin in 1955-1958 years]. Moscow-Leningrad: Publishing House «Transport». P.13-78 [in Russian].

Luke S.R. 1982. Catalog of the bentjic invertebrate collections, Echinodermata // Scripps Institution of Oceanography Reference Series. Vol.82-5. P.1-66.

Maluf L.Y. 1988. Composition and distribution of the central eastern Pacific echinoderms // Natural History Museum of Los Angeles County, Technical Reports. No.2. P.1-242.

McKnight D.G. 1973. Stalked crinoids from the New Zealand region // New Zealand Oceanographic Institute Records. Vol.1. No.14. P.199-210.

Menzies R.J. 1963. General results of biological investigations on the deep-sea fauna made on the U.S.N.S Eltanin (U.S.A.R.P.) during cruise 3 between Panama and Valparaiso, Chile in 1962 // International Revue der gesamten Hydrobiologie. Bd.48. H.2. S.185-200.

Menzies R.J., George R.Y., Rowe G.T. 1973. Abyssal environment and ecology of the World Ocean. New York: John Wiley. 488 p.

Mironov A.N. 2000. [New taxa of the stalked crinoids of the suborder Bourgueticrinina]//Zoologicheskii Zhurnal. Vol.79. No.6. P.712-728 [in Russian, with English summary].

Oji T., Kitazawa K. 2008. Discovery of two rare species of stalked crinoids from Okinawa Trough, southwestern Japan, and their systematic and biogeographic implications // Zoological Science. Vol.25. No.1. P.115-121.

Pisera A., Dzik J. 1979. Tithonian crinoids from Rogoznik (Pieniny Klippen Belt, Poland) and their evolutionary relationships // Eclogae Geologicae Helvetiae. Vol.72. P. 80-849.

Rasmussen H.W., Sieverts-Doreck H. 1978. Articulata Classification // R.C. Moore, C. Teichert (eds.). Trea- 
tise on Invertebrate Paleontology, Part T, Echinodermata 2 (3). Boulder, Colorado and Lawrence, Kansas: Geological Society of America and University of Kansas Press. P.813-928.

Roux M. 1980. Les crinoïdes pédonculés (Echinodermes) photographiés sur les dorsales océaniques de l'Atlantique et du Pacifique. Implications biogéographiques // Comptes Rendus de l'Academie des Sciences de Paris. Vol.D291. No.11. P.901-904.

Roux M. 1987. Evolutionary ecology and biogeography of recent stalked crinoids as a model for the fossil record // Echinoderm Studies. Vol.2. P.1-53.
Roux M., Messing Ch.G., Améziane N. 2002. Artificial keys to the genera of living stalked crinoids (Echinodermata) // Bulletin of Marine Science. Vol.70. No.3. P.799-830.

Salamon M.A., Gorzelak P. 2007. Evidence of shallowwater cyrtocrinids (Crinoidea) from the Callovian of Poland // Neues Jahrbuch fur Geologie und Paläontologie - Abhandlungen. Vol.244. No.3. P.257-260.

Smirnov A.V., Smirnov I.S. 2006. [New echinoderms findings in the Laptev Sea (1993-1998 expeditions)] // Issledovaniya fauni morei. Vol.56 (64). P.93-147 [in Russian, with English summary]. 